\title{
Does TV edutainment lead to farmers changing their agricultural practices aiming at increasing productivity?
}

Article

Accepted Version

Creative Commons: Attribution-Noncommercial-No Derivative Works 4.0

Areal, F., J., Clarkson, G., Garforth, C., Barahona, C., Dove, M. and Dorward, P. (2020) Does TV edutainment lead to farmers changing their agricultural practices aiming at increasing productivity? Journal of Rural Studies, 76. pp. 213229. ISSN 0743-0167 doi:

https://doi.org/10.1016/j.jrurstud.2020.03.001 Available at https://centaur.reading.ac.uk/89547/

It is advisable to refer to the publisher's version if you intend to cite from the work. See Guidance on citing.

To link to this article DOI: http://dx.doi.org/10.1016/j.jrurstud.2020.03.001

Publisher: Elsevier

All outputs in CentAUR are protected by Intellectual Property Rights law, including copyright law. Copyright and IPR is retained by the creators or other copyright holders. Terms and conditions for use of this material are defined in the End User Agreement. 


\section{CentAUR}

Central Archive at the University of Reading

Reading's research outputs online 
1 Does TV edutainment lead to farmers changing their agricultural practices aiming at

$2 \quad$ increasing productivity?

\section{Abstract}

4 We investigate the influence of an agricultural TV edutainment programme on farmers'

5 decisions to implement changes of agricultural practices. We use data obtained from a survey

6 conducted to 1,572 households in Kenya across the target areas of a TV edutainment

7 programme, Shamba-Shape-Up (SSU). A conceptual framework is developed to account for

8 the interaction between farmers watching SSU internal factors including farmer's and

9 household's characteristics, farmer's views on farming and farmer's trust on sources of

10 influence and farmer's decision to change their agricultural practices. Structural equations and probit models are used to understand how watching edutainment TV programme Shamba Shape-Up (SSU) along with farmers and household's characteristics, famer's views on farming and farmer's trust on sources of information affect maize and dairy farmer's probability to make changes to agricultural practices shown in SSU. We find that SSU has an influence on maize and dairy farmers' decisions to implement changes of agricultural practices. Farmers who watch SSU have a higher probability to implement a greater number of agricultural practices. However, SSU influence varies depending on the agricultural practice recommended as well as on the reasons that farmers have for watching the programme. The probability of implementing agricultural practices shown on SSU was dependent the associated difficulty of making such changes. Edutainment TV can be a viable channel to nudge farmers to implement practices that contribute to face local and global challenges such as adapting and mitigating climate change, poverty reduction, increasing productivity and income of smallholders in developing countries. 
Key words: Edutainment, agricultural practices, Shamba Shape-Up

\section{Introduction}

Increasing the number of changes farmers make in their agricultural practices that aim at increasing productivity and producing sustainable outputs by farmers is key to achieving Sustainable Development Goals such as no poverty and zero hunger (Pretty et al., 2003). Importantly, food insecurity and poverty are interconnected with other important issues such as undernourishment, which affect significant parts of the population in developing countries. For instance, in Sub-Saharan Africa undernourishment affected $22.7 \%$ of the population in 2016 (FAO and OCDE, 2018). Increasing smallholder farmers' income and adapting to climate change to mitigate its effects on food security through the use of more productive and sustainable agricultural practices is crucial to solve not only food security but also contributes to tackle poverty and undernourishment. In order to increase farmers' use of such beneficial practices, understanding the reasons behind farmer's decision (whether or not to make a change) is key. Typically, studies investigating the determinants of the innovation in smallholder agriculture put emphasis on how socio-economic characteristics of the household/farmer, sources of information and risk aspects influence farmer's decisions regarding the use of new farming practices (i.e. innovation) (Boucher et al., 2008; DEFRA, 2019). Attention has been paid to how membership of agricultural organisations (e.g. unions, cooperatives, etc.) and access to financial services (e.g. institutional credit provisions) may influence farmers' adoption of agricultural practices in Sub Saharan Africa (Abate et al., 2016; Abebaw and Haile, 2013a; Teklewold et al., 2013) but other aspects, such as policy measures (Areal et al., 2012) and their impact on innovation have received relatively less attention. 
One channel, which has received little attention so far but may contribute to increasing innovation and agricultural productivity is the broadcast of TV edutainment programmes aimed at showing farmers solutions to agricultural problems. Therefore, TV edutainment programmes can potentially influence farmer's decision to implement more productive and sustainable agricultural practices (Clarkson et al., 2018).

Edutainment, a term that refers to TV programmes, computer games, internet sites, videos and films, workshops, theme parks that mix entertainment and education material, has a number of qualities such as helping learners, focusing the attention and facilitating individuals internalising difficult subjects with the simulation and visual methods representing real life conditions (de Fossard, 2008; Okan, 2003). Although edutainment is usually referred to children educational programmes it can target all ages through edutainment TV shows, DIY, theme park style educational centres (Creighton, 2007) and events such as educational workshops (Feenstra et al., 2015). TV edutainment or educational $\mathrm{TV}$, which refers to TV programmes that mix entertainment to educational material (Colace et al., 2006), has risen worldwide seeking to increase programmes' audience by capturing viewers with entertainment motives rather than educational motives to watch the programme (Caraher et al., 2009). The effects of edutainment TV shows has been examined from different perspectives with relationships between watching edutainment TV shows and changes in habits being found (De Backer and Hudders, 2016; Dway et al., 2015; Flora et al., 2014; Forster et al., 2016; Jana et al., 2015; Jenkins et al., 2012). There are a number of TV edutainment programmes in Sub-Sahara African countries such as Kuapa in Ghana and Kilimo Biashara, Shamba Shape Up (SSU) and Mazingira 24 in Kenya which aim to help farmers increase their productivity by showing them how to implement agricultural practices. Little research has been done so far on the effects of TV edutainment on agriculture productivity (Clarkson et al., 2018). One exception is the work by Clarkson et al. (2018) who 
estimated that the interaction of Kenyan farmers with one edutainment TV program, SSU in

Kenya, benefitted 430,000 farmers through increased income and / or a range of related social benefits.

Here, we analyse how the implementation of agricultural practices, recommended in SSU, a

TV edutainment program, by maize and dairy farmers in Kenya may be associated with watching the SSU TV edutainment programme and reasons for watching the programme amongst other factors including farmer's and household's characteristics, farmer's views on farming and farmer's trust on sources of influence. SSU goes beyond the broadcasting of information, from a pre-scripted lecture or documentary. It brings experts to a farm household so that the audience is able to watch the interactions between farmers and experts, understanding and empathising with the farmer and hoping to see a positive way forward for the farm. If the farm has been chosen well then the audience will identify with the situation and the challenges, doubts and aspirations of the host household.

Kenya is a useful location to explore the role of edutainment in agricultural development since the SSU programme is broadcasted to important agricultural areas of the country. To our knowledge this is the second paper that investigates edutainment within the agricultural context and it is the first to examine ways in which farmers engage to the SSU TV programme and how these may be associated with favouring or discouraging the implementation of agricultural technologies. Although SSU covers a wide range of topics across the agricultural spectrum we focus our analysis on recommendations made to maize and dairy farmers using information obtained through a questionnaire disseminated to maize and dairy farmers who are watchers and non-watchers of SSU. We measure the changes of farmer's agricultural practices to those shown in the edutainment programme in two ways: 1) change as a whole: farmers implementing a relatively large number of practices during the last 12 months/season and 2) a specific change: farmers implementing a specific agricultural 
practice. Using these we investigate the association between watching SSU and farmers' reasons for watching SSU as well as other as at the household level as well as the community level (e.g. other sources of information) with such changes in agricultural practices.

\subsection{Shamba Shape up (SSU)}

SSU is a makeover educational TV programme broadcast on Citizen Television, in Kenya in 39 weekly, 30 minute instalments throughout the main cropping season. Each episode is broadcast twice a week, once in Swahili (on Sunday afternoon) and once in English (on Saturday afternoon). Each weekly instalment consists of a visit to a selected farm (Shamba) where current issues and problems facing a host farmer and household are discussed. Solutions and opportunities are identified with the help of experts. Potential changes to the farm enterprises are explored through demonstration and explanation. In some cases, a contribution to the costs of making changes to effect solutions is paid by SSU. Each SSU instalment covers up to five topics broadly relevant to the stage of the cropping season when the broadcast takes place. SSU covers a wide range of topics across the agricultural spectrum. The programme also broadcasts widely in Tanzania and less widely in Uganda.

The following sections are dedicated to the description of the methodology and empirical approaches used, the data, presentation of the results and a final section that concludes.

\section{Materials and methods}

Factors influencing farming decisions taken by farm households can be classified into external factors such as world/regional economic situation, market conditions and physical infrastructures, international and national political situation as well as seasonal and weather factors, and internal factors: farm household's characteristics, composition, access to 
resources, attitudes to risk and its goals. In addition, farm household decisions can be influenced by household members interacting with sources of information and influence. Examples of these are their own network of family and friends, mass media, general public,

124 NGOs and commercial providers of information. SSU is both a source of information and 125 influence on farmer's decisions to use more productive and sustainable agricultural practices and a potential source of influence on other innovation system actors (input dealers, extension workers, traders, etc...). We focus here on the interaction between the internal factors and farmer's decision to change the agricultural practices used. We acknowledge that this study could be framed into existing theories such as the theory of reasoned action (Fishbein, 1967), theory of planned behaviour (Ajzen, 1991, 1987, 1985) and the technology acceptance model (Davis, 1989; Davis et al., 1989), however, although elements included in these theories such as attitudes, subjective norms and perceived behavioural control, perceived usefulness and perceived ease of use can be identified under our approach we decided to use a different structure that puts emphasis on the association between edutainment $\mathrm{TV}$, reasons to watch the edutainment programme and farmer's behaviour (implementing agricultural practices).

\subsection{Conceptual framework}

We developed a framework for making changes in agricultural practices by farm households including potential drivers on farmer's decisions to change their current agricultural practices for those shown in the SSU TV programme (Figure 1). Figure 1 shows which elements may influence change along with the methodological steps followed. 


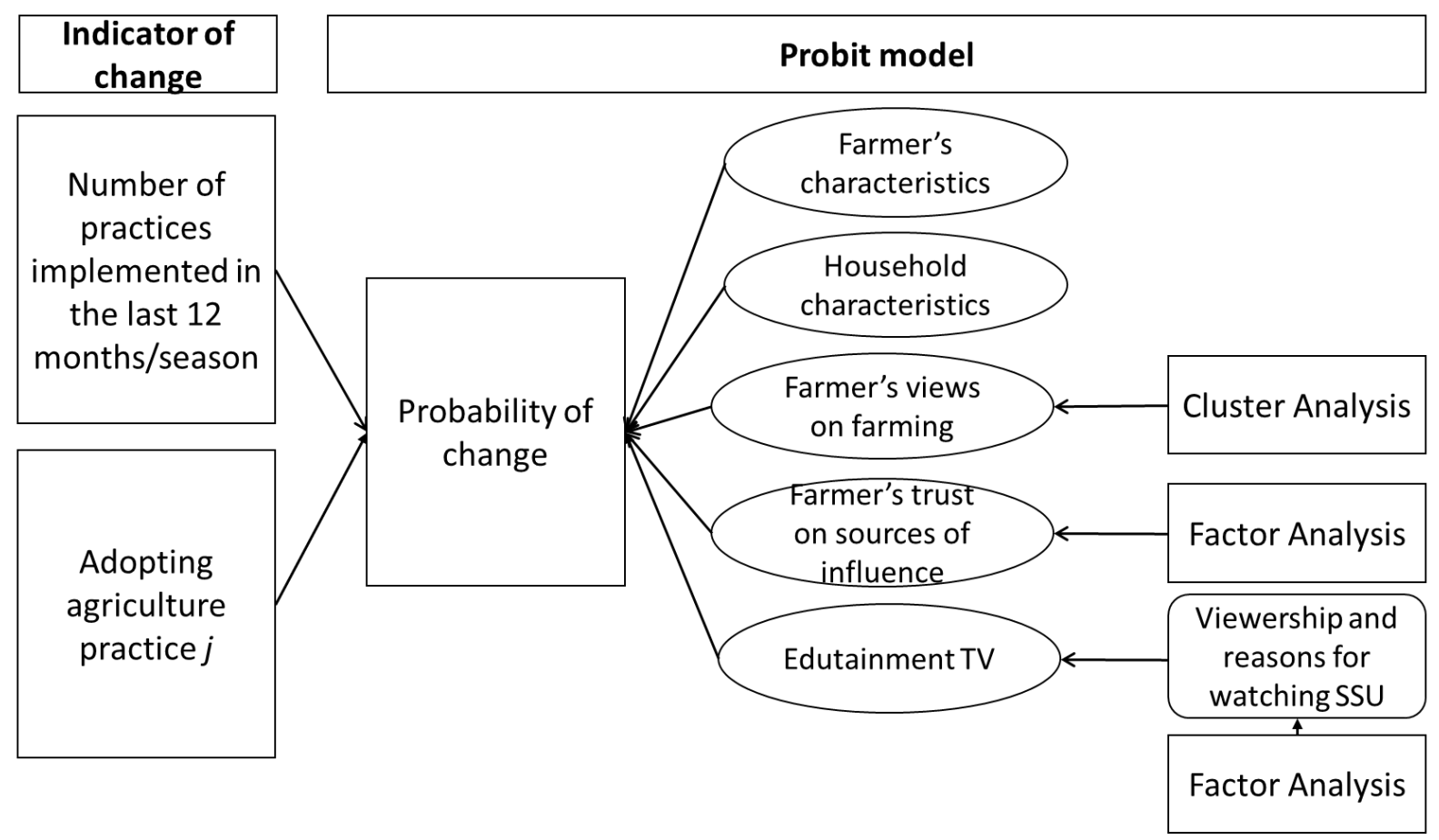

Figure 1. Framework for making changes in agricultural practices

152 We use the total number of agricultural practices implemented/applied/changed during the last season (maize) and during the last 12 months (dairy) as an indicator of farmers changing agricultural practices. This indicator gives us a "broad" picture on the farmer's decision to make changes to their agricultural practices. We use a second indicator, which accounts for a farmer's decision to implement individual agricultural practices. This gives us a "specific"

157 picture on which agricultural practices farmers are more likely to change and the reasons for these changes.

160 Agricultural practices shown on the SSU TV programme are shown in table 1 for maize and dairy enterprises. 
Table 1: Specific agricultural practices promoted by SSU in maize and dairy enterprises

\begin{tabular}{|c|c|}
\hline Maize Practices & Dairy Practices \\
\hline Apply fertilizer at planting & Increase the size of your dairy herd \\
\hline $\begin{array}{l}\text { Apply fertilizer mixed with manure at } \\
\text { planting }\end{array}$ & Plant Napier Grass for the first time \\
\hline Apply manure at planting & Increase the area of Napier Grass \\
\hline Purchase maize seed from a agro-dealer/shop & Feed cows using chopped Napier Grass \\
\hline $\begin{array}{l}\text { Plant a crop in your maize plot as an } \\
\text { intercrop }\end{array}$ & Spray dairy cows for ticks or lice \\
\hline $\begin{array}{l}\text { Purchased packed seeds for intercropping } \\
\text { from a shop/agro dealer }\end{array}$ & Deworm your dairy cows \\
\hline $\begin{array}{l}\text { Planted your maize at this distance } 2.5 \\
\text { feet } / 75 \mathrm{~cm} \text { between rows and } 1 \text { foot } / 30 \mathrm{~cm} \\
\text { between plants }\end{array}$ & Treat for mastitis \\
\hline Apply top dressing fertilizer & Make and feed hay \\
\hline Weed your maize two times (or more) & Make and feed silage \\
\hline Planted Desmodium in the maize field & Purchase supplement feeds or salt licks \\
\hline Use Actellic in your stored maize & Ensure cows have enough water all day \\
\hline Test the soil in your farm & $\begin{array}{l}\text { Since March } 2012 \text { Construct a new dairy } \\
\text { shed with a floor, easy to clean, has dry space } \\
\text { for the cow and is protected against wind } \\
\text { Since March } 2012 \text { Make improvements to } \\
\text { your dairy cow shed so that it is easy to clean, } \\
\text { has dry space for the cow and is protected } \\
\text { against wind }\end{array}$ \\
\hline
\end{tabular}

Hence we interpret change in agricultural practices in two ways: the first is change as farmer implementing a relatively large number of practices during the last 12 months/season. Under this view, we classify farmers into two groups: those who uptake a substantial number of practices during the last 12 months/season ${ }^{1}$ (i.e. the number of practices implemented is above the median) and those who do not (i.e. the number of practices implemented is below

\footnotetext{
${ }^{1}$ The median values for number of practices implemented for maize and dairy farmers are 3 and 4 respectively. Therefore two variables were created: changes maize taking a value of 1 if the number of changes is greater than 3 and takes a value of 0 otherwise and changes dairy which takes a value of 1 if the number of practices implemented is greater than 4 and takes a value of 0 otherwise.
} 
the median). The second way we interpret change is as a change at the specific agricultural practice level (i.e. a farmer would change if she or he implements a particular agricultural practice). In this case, we analyse change at a practice level rather than at change as a whole (i.e. large number of practices). Whereas the first approach allows us to investigate whether a farmer has made a significant number of changes and what factors, including TV edutainment measured as SSU viewership, are associated to these changes the second approach allows us to investigate in which of all agricultural practices analysed changes have occurred, and what factors are associated to them, again focusing on whether TV edutainment is associated with change in agricultural practices. More specifically, the probability of changing current agricultural practices (i.e. the probability of implementing a relatively large number of practices; the probability of implementing a particular agricultural practice) is explained through a number of explanatory variables that account for farmer characteristics (farmer's age, gender, education level and income), household characteristics (household female ratio, household children ratio), farmer's general views on farming, their level of trust in sources of influence of change and SSU viewership. We use SSU viewership as an indicator of edutainment that enables us to test whether edutainment (i.e. watching SSU) is associated with changes in agricultural practices. Farmer's level of education is taken into account using dummy variables (no formal education, primary education, secondary education, college after secondary and university). Farmer income, measured through the Progress out of Poverty Index $\left(\mathrm{PPI}^{2}\right)$, is included in the model using three dummy variables: low PPI that takes a value of 1 if their PPI score is lower than 40 and 0 otherwise; normal PPI takes a value of 1 if their PPI score is between 40 and 69 and takes a value of 0 otherwise; high PPI takes a value of 1 if their PPI is greater than 70 and 0 otherwise $^{3}$. Household characteristics include the

\footnotetext{
${ }^{2}$ In October 2017 the PPI was rebranded to Poverty Probability Index http://www.progressoutofpoverty.org

${ }^{3}$ The figures determining the PPI groups are the quartiles of the distribution of the PPI in the sample.
} 
household female ratio (number of adult women divided by total number of adults in the household), household children ratio (number of children in the household divided by the total number of members in the household), household income is captured by the PPI indicator. Farmer's general views and attitudes towards farming are incorporated after conducting a cluster analysis. A cluster analysis (CA), a statistical method for identifying homogenous groups of objects called clusters, was performed on the statements related to farmers' perceptions and views on farming in general. The aim of conducting this analysis was to group farmers into two distinct groups according to their general perceptions and views on farming. For this we used a partitioning method (more precisely, k-means) ${ }^{4}$. A factor analysis (principal component analysis) was used to group sources of information into relatively small common themes. We also collected information on farmer's reasons for watching SSU. Farmers had to explain their reasons for watching SSU through scoring 13 1-5 Likert scale statements ${ }^{5}$. A factor analysis (principal component analysis) was used to group reasons for watching SSU into relatively small common reasons. These themes and reasons obtained from a factor analysis conducted on sources of information and reasons for watching SSU were then incorporated in the model as explanatory variables ${ }^{6}$.

\subsection{Survey and questionnaire}

A survey was conducted with 1,572 households across the target areas of SSU viewership with 893 SSU-viewers and 679 non-viewers. Prior to the survey a listing survey was

\footnotetext{
${ }^{4}$ See Table A.1 in Appendix for correlations between statements. Variables used in the cluster analysis are not highly correlated $(<0.9)$ which would be problematic. See Table A.2 in Appendix for average scores regarding farmer's views and attitudes towards farming by cluster

${ }^{5}$ We initially developed 20 statements during the conceptualisation of the problem stage. We piloted the questionnaire with the initial 20 statements after which the research team re-evaluated the statements, refined them and reduced their number to the final 13 statements.

${ }^{6}$ Factors were extracted for eigenvalues greater than one and varimax rotation was adopted, which guarantees that the obtained factors are orthogonal reducing the risk of multicollinearity in the probit models.
} 
conducted with 9,885 households in 119 Enumeration Areas (EAs) randomly selected. This was necessary to accurately establish the level of TV ownership and SSU viewership in the designated study area, as there were previously no definitive figures on TV ownership or the

221 number of people watching SSU in the area. The classification between SSU-viewers and

222 SSU non-viewers was based on respondents' statements as to whether they were SSU

223 viewers or not. The survey specifically targeted selected regions of Kenya based on SSU

224 broadcasting areas as outlined by $\mathrm{Mediae}^{7}$ (figure 2).

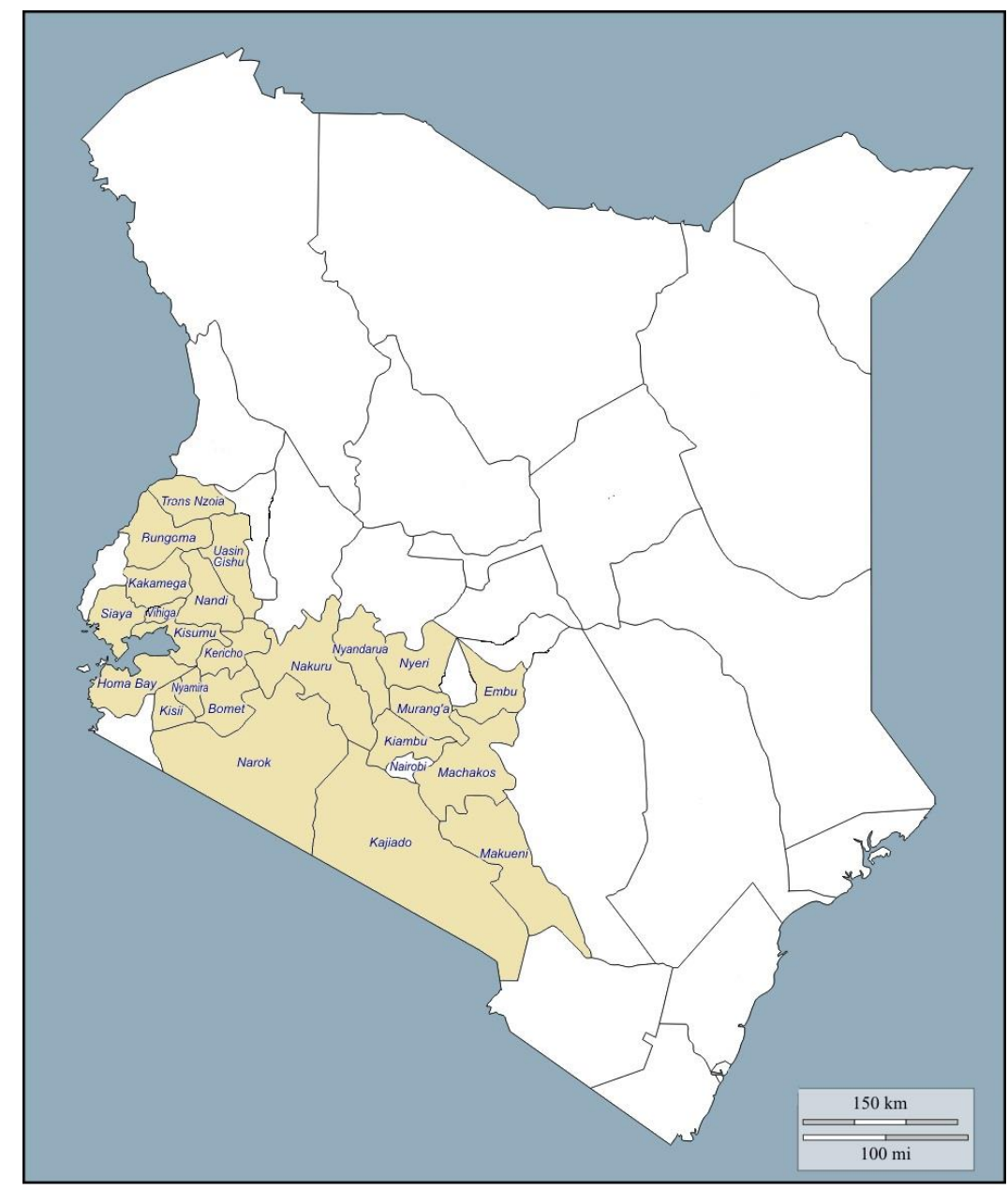

226 Figure 2. Map of Kenya highlighting study area

\footnotetext{
${ }^{7}$ Mediae (www.mediae.org) are the producers of Shamba Shape Up. Mediae provided with information on the regions where SSU was broadcasted in Kenya.
} 
228 Data collection began on $17^{\text {th }}$ April 2014 and ran through to $30^{\text {th }}$ May 2014 using a

229 questionnaire. On average a personal interview with a farmer took 80 minutes. The

230 questionnaire consisted of a number of sections including socio-economic characteristics of

231 the household; SSU processes and influences; farmer influencing sources; perceptions and

232 views about SSU including (i.e. reasons to watch SSU); general perceptions and views about

233 farming; level of trust on sources of information. One to five Likert scales were used in

234 questions related to perceptions and views about SSU and general perceptions and views

235 about farming. The questionnaire was inputted into Survey to go - PC Surveyor, which is an

236 application for conducting surveys.

237 The practices recommended and demonstrated by SSU differ by enterprise and only the most commonly promoted practices were analysed. Overall 12 practices were analysed for maize and 13 for dairy (table 1$)^{8}$.

240 Table 2 shows the descriptive statistics of the data used in the analysis.

\footnotetext{
${ }^{8}$ These agricultural practices are not new, they have been promoted in the locations covered by a range of organisations.
} 


\begin{tabular}{|c|c|c|c|c|c|}
\hline \multicolumn{3}{|l|}{ Maize } & \multicolumn{3}{|l|}{ Dairy } \\
\hline Variable & Mean & SD & Variable & Mean & SD \\
\hline \# Changes & 0.52 & 0.50 & \# Changes & 0.40 & 0.49 \\
\hline Apply fertiliser at planting & 0.53 & 0.50 & Increase the size of your dairy herd & 0.18 & 0.38 \\
\hline Apply fertukuser mixed with manure at planting & 0.08 & 0.27 & Increase the area of Napier Grass & 0.15 & 0.35 \\
\hline Apply manure at planting & 0.21 & 0.40 & Feed cows using chopped Napier Grass & 0.46 & 0.50 \\
\hline Purchase maize seed from agr-dealer/shop & 0.61 & 0.49 & Spray dairy cows for ticks or lice & 0.74 & 0.44 \\
\hline Plant a crop in your maize plot as an intercrop & 0.48 & 0.50 & Deworm your dairy cows & 0.83 & 0.38 \\
\hline $\begin{array}{l}\text { Purchased packed seeds for intercropping from a } \\
\text { shop/agro dealer }\end{array}$ & 0.11 & 0.31 & Treat for mastitis & 0.15 & 0.36 \\
\hline Planted your maize at this distance $2.5 \mathrm{feet} / 75 \mathrm{~cm}$ & & & Purchase supplement feeds or salt licks & & \\
\hline between rows and 1 foot $/ 30 \mathrm{~cm}$ between plants & 0.28 & 0.45 & & 0.65 & 0.48 \\
\hline Apply top dressing fertiliser & 0.35 & 0.48 & Ensure cows have enough water all day & 0.56 & 0.50 \\
\hline Weed your maize two times (or more) & 0.57 & 0.50 & SSUviewers & 0.59 & 0.50 \\
\hline Use Actellic in your stored maize & 0.18 & 0.39 & F1 - Education/Usefulness/Empathy & 2.93 & 0.71 \\
\hline SSUviewers & 0.57 & 0.50 & F2 - Entertainment/fun & 2.55 & 0.68 \\
\hline F1 - Education/Usefulness (empathy - dairy) & 2.99 & 0.68 & F3 - Entertainment/frinends & 2.38 & 0.67 \\
\hline F2 - Empathy & 2.88 & 0.64 & Media_trust (TV news, magazine) & $-7 . \mathrm{E}-03$ & 1.00 \\
\hline F3 - Entertainment/fun & 2.79 & 0.72 & $\begin{array}{l}\text { External1_trust (Agro- } \\
\text { dealers/shopkeeper/agrivet) }\end{array}$ & 0.08 & 0.98 \\
\hline F4 - Entertainment/friends & 2.15 & 0.70 & $\begin{array}{l}\text { External2_trust (NGO/Agriculture } \\
\text { extension officer) }\end{array}$ & 0.03 & 0.96 \\
\hline Media_trust (TV news, magazine) & $-9 . \mathrm{E}-03$ & 1.01 & Traditional_trust (friends/family) & 0.06 & 1.02 \\
\hline
\end{tabular}


External1_trust (Agro-dealers/shopkeeper/agrivet)

External2_trust (NGO/Agriculture extension officer)

Traditional_trust (friends/family)

Farmer's Age

Gender

Primary education

Secondary education

College after secondary/University

Cluster F1 (farming as a business, enjoying farming)

$\mathrm{HH}$ female ratio

$\mathrm{HH}$ children ratio

Cropland area/number of cows

Normal PPI

High PPI

$\begin{array}{rrlrr}\text {-2.E-03 } & 1.00 & \text { Farmer's Age } & 45.90 & 14.72 \\ & & \text { Gender } & 0.46 & 0.50 \\ -0.01 & 1.00 & & 0.45 & 0.50 \\ 9 . \text { E-04 } & 0.99 & \text { Primary education } & 0.34 & 0.47 \\ 43.35 & 14.41 & \text { Secondary education } & 0.15 & 0.36 \\ 0.49 & 0.59 & \text { College after secondary/University } & & \\ & & \text { Cluster F1 (farming as a business, enjoying } & 0.43 & 0.50 \\ 0.46 & 0.49 & \text { farming) } & 0.51 & 0.20 \\ 0.33 & 0.47 & \text { HH female ratio } & 0.40 & 0.23 \\ 0.15 & 0.36 & \text { HH children ratio } & & \\ & & \text { Cropland area/number of cows } & 2.11 & 2.61 \\ 0.44 & 0.50 & 0.60 & 0.49 \\ 0.51 & 0.21 & \text { Normal PPI } & 0.28 & 0.45 \\ 0.41 & 0.23 & \text { High PPI } & & \\ 1.76 & 2.28 & & & \\ 0.58 & 0.49 & & & \\ 0.28 & 0.45 & & \end{array}$




\subsection{Statistical analysis}

244 The information collected through the survey regarding a) farmers' perceptions and views on

245 farming; b) farmers' level of trust in sources of information; and c) farmers' reasons for

246 watching the edutainment TV programme SSU was organised and simplified by using cluster

247 analyses and factor component analysis and incorporated into models to explain the farmer's

248 probability of changing current agricultural practices. This enabled us to find factors behind

249 reasons for watching SSU such as education/usefulness; empathy with farmers appearing in

250 the programme; entertainment/fun and entertainment associated to watching the programme

251 in company of friends. Hence, we are able to investigate how the different ways that SSU has

252 to engage with audiences (e.g. through education, entertainment, empathy) may influence

253 farmer's decision to implement agricultural practices shown in the TV programme.

254 We conduct two separate analyses, one for each indicator (total number of agricultural

255 practices changes and changes of specific agricultural practices). Firstly, two simultaneous

256 equations models (SEMs), one for maize and one for dairy, based on the number of

257 agricultural practices implemented in the last 12 months/season were estimated. Secondly, a set of SEMs analysing relevant individual agricultural practice (for maize and for dairy) were estimated. By using SEM for a dichotomous endogenous variable we deal with a particular problem of endogeneity, simultaneity. This approach allows us to test whether the probability of implementing agricultural practices and being a SSU viewer are jointly determined (i.e. the errors of both equations (1) and (2) below are correlated). In the case that implementing agricultural practices and being a SSU viewer are jointly determined we provide results from the SEM; otherwise we provide the results for the probit regressions (1) and (2) below ${ }^{9}$. These SEMs can be described as follows:

\footnotetext{
${ }^{9} Z_{i}$ is exogenous if the error term in equation (1), $\varepsilon_{i}$ is uncorrelated with the error term in equation (2), $\xi_{i}$. We tested whether this correlation is 0 or not. If they are correlated we analyse a SEMs, otherwise we analyse two probit models.
} 


$$
\begin{aligned}
& y_{i}=x_{i} \beta+z_{i} \gamma+\varepsilon_{i} \\
& z_{i}=x_{i} \delta+v_{i} \theta+\xi_{i}
\end{aligned}
$$

where $y_{i}$, depending on the type of model, can be the probability of farmer $i$ implementing a number of agricultural practices (i.e. a number of practices greater than the sample median of number of practices implemented in the last 12 months/season) or the probability of farmer $i$

272 implementing a particular agricultural practice in the last 12 months/season; $x_{i}$ is a

$2731 \times k$ vector of exogenous explanatory variables for farmer $i ; z_{i}$ is a $1 \times k$ vector of endogenous variable(s) for individual $i$; $v_{i}$ is a $1 \times m$ vector of variable(s) that explain $z_{i}$ (apart from $x_{i}$ ) for individual $i ; \beta, \gamma, \delta$, and $\theta$ are vectors of parameters to be estimated; and $\varepsilon_{i}$ and $\xi_{i}$ are error terms. A test for exogeneity of $z$ is equivalent to test whether $\varepsilon_{i}$ and $\xi_{i}$ are independent $\left(H_{0}: \rho=0 ; \rho\right.$ being the correlation between $\varepsilon_{i}$ and $\left.\xi_{i}\right)($ Cameron and Trivedi, 2010). As pointed out above if $\varepsilon_{i}$ and $\xi_{i}$ are found to be correlated SEMs estimates are reported, otherwise (i.e. if evidence of simultaneity is not found) probit estimates are reported.

All explanatory variables $\left(x_{i}\right.$ and $\left.v_{i}\right)$ in the model are treated as exogenous variables except for SSU viewership $\left(z_{i}\right)$ which is treated as endogenous for the following reason ${ }^{10}$. Since our aim is to study whether watching SSU leads to change (i.e. increasing likelihood of implementing new agricultural practices) we are concerned that the explanatory variable SSU viewership may be correlated with other factors that can affect change. In order to control for this form of endogeneity we use information about whether the farmer has a TV and it is in a working condition as an instrumental variable for explaining SSU viewership (i.e. the

\footnotetext{
${ }^{10} \mathrm{An}$ exogenous variable is defined as any variable that is uncorrelated with the error term in the model. In other words, an exogenous variable is any variable that is assumed to be determined outside the model. On the other hand, an endogenous variable is any variable that is presumed to be correlated with the error term in the model.
} 
likelihood of implementing a greater number of practices/ a particular practice is simultaneously explained with SSU viewership) ${ }^{11}$. Consequently, we generated a dummy variable, TV works, that takes a value of 1 if the household has a TV set that is in working condition and takes a value of 0 otherwise.

\section{Results and discussion}

We first present the results for the elements that are integrated as explanatory variables in the models described above (equations (1) and (2)) through the use of cluster and factor analysis $^{12}$. These are farmers' perceptions and views on farming; farmers' level of trust on sources of information and farmers' reasons for watching the edutainment TV programme SSU. Then we present and discuss the results of the 2 models for a) explaining the number of agricultural practices implemented in the last 12 months/season, and b) explaining the specific agricultural practices implemented in the last 12 months/season.

\subsection{Farmers' perceptions and views on farming}

We identified two distinct groups, F1 and F2 using cluster analysis (Figure 3 and Appendix 1 and 2). Group F1 includes farmers who are relatively more positive about trying new things, enjoying farming, seeing farming as a business and as a way to feed the $\mathrm{HH}$ whereas group F2 is formed by farmers who tend to think more that their farm is too small to care about

\footnotetext{
${ }^{11}$ We selected the variable having a TV in working condition since is unlikely to be correlated with any unobservable factors influencing the dependent variable (i.e. the probability of implementing a number of agricultural practices or the probability of a particular agricultural practice in the last 12 months/season). ${ }^{12}$ Previous work on adoption of multiple agricultural practices has put emphasis on accounting for the possibility that adoption of different agricultural practices may be correlated (Teklewold et al., 2013). We have estimated a multivariate probit model (Cappellari and Jenkins, 2003) for dairy agricultural practices, which does not show signs of endogeneity. Results are similar to the ones presented here with no significant changes in the estimated coefficients, with the exception that SSU viewers are more likely of deworm their dairy cows at $10 \%$ significance level.
} 
making changes; find relatively more difficulties in knowing who to contact about inputs and materials; and farmers who are relatively more sceptical that new technologies will work. We use a dummy variable that takes a value of 1 if the farmer is classified as belonging to cluster F1 and takes a value of 0 otherwise.

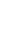

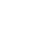

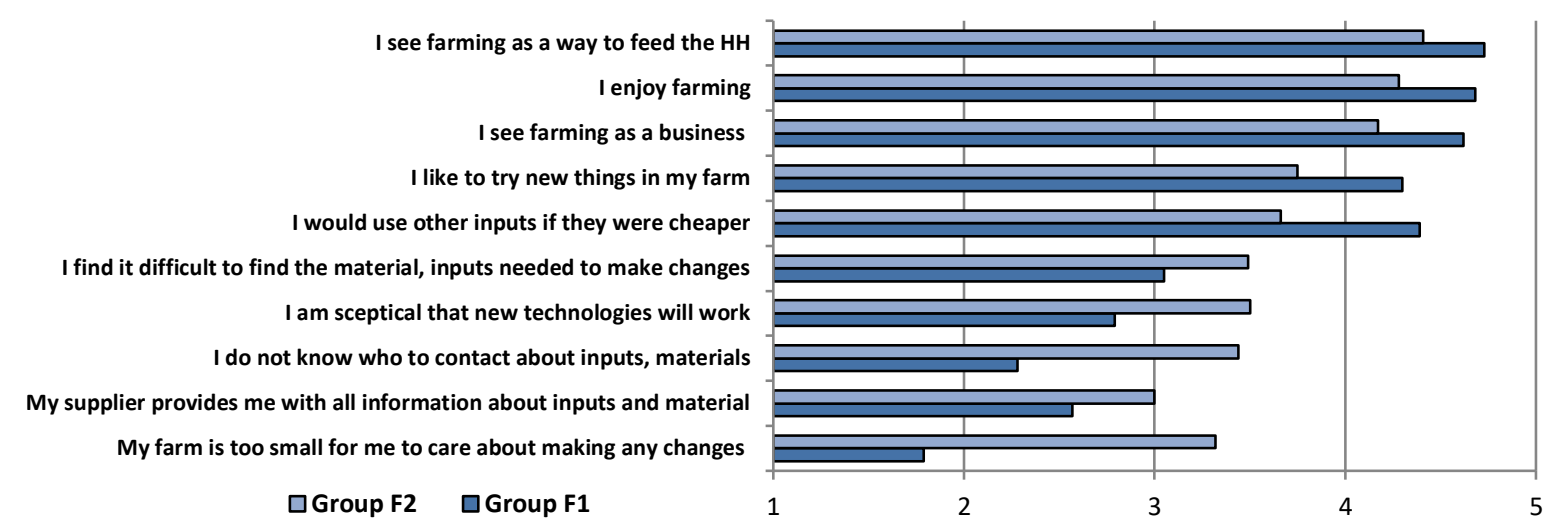

Figure 3: Average score to statements related to farming by cluster

\subsection{Farmers' level of trust in sources of information}

The analysis of the sources of influence on change is focused on level of trust in sources of information including farmer's social network and additional media of information. We asked farmers to evaluate their level of trust in sources of information such as: family and friends, agricultural extension officers, agro-dealers/shopkeepers, agro-vets and religious institutions, non-governmental organisations, radio, TV news programmes, SSU TV programme, other farming programmes, newspapers-magazines. 
325 Principal component analysis produced a four factor solution which explains $67.8 \%$ of the

326 total variance on the level of trust on sources of information ${ }^{13}$. Table 3 shows the factor

327 loadings obtained for the rotated component matrices. The first factor (Media_trust) is

328 associated with trust in sources related to general media (i.e. TV news programme, other TV

329 programme on agricultural issues, newspapers/magazines); the second factor

330 (External1_trust) is associated with trust in sources of information that involve the farmer

331 usually contacting these sources (agro-dealers/shopkeepers, agri-vets); the third component

332 (External2_trust) is associated with trust on sources of information that usually come to the

333 farm to provide advice (agricultural extension officers and NGOs) whereas the fourth

334 component (Traditional_trust) is associated with trust on traditional sources of information

335 such as radio and friends and family.

Table 3: Factor loadings for level of trust on information sources

\begin{tabular}{lcccc} 
& Factor 1 & Factor 2 & Factor 3 & Factor 4 \\
\hline TV news programme & 0.82 & & & \\
Other TV programme & 0.83 & & & \\
Newspaper/magazine & 0.70 & & & \\
Agro-dealers/shopkeeper & & 0.87 & & \\
Agrivet & & 0.84 & & \\
Agricultural extension officer & & 0.76 & \\
NGO & & 0.64 & \\
Religious Institution & & -0.47 & 0.90 \\
Friends or family & & & 0.46 \\
Radio & & & \\
\hline
\end{tabular}

Farmers' reasons for watching the edutainment $T V$ programme $S S U$

\footnotetext{
${ }^{13}$ The Kaiser-Meyer-Olkin measure of sampling adequacy (Kaiser, 1970) was 0.80 indicating the convenience of conducting factor analysis.
} 
Farmers who were viewers the edutainment TV programme were further asked about the reasons behind watching SSU. Farmers were asked to evaluate a total of 13 statements by scoring using a 1 to 5 Likert scale, being 1 completely disagree and 5 completely agree. We conducted another principal component analysis to group the different reasons for farmers watching SSU into relatively small common themes that represent the relationship of farmers and the TV programme ${ }^{14}$. Tables 4 and 5 show the factor loadings for maize and dairy farmer's watching SSU, respectively. A total of four and three factors were found that explain $56 \%$ and $48 \%$ of the variance on the reasons for maize and dairy farmers to watch SSU TV edutainment programme, respectively.

The first factor for maize farmers is related to the farmer finding the programme useful in terms of new learning and decision making. Statements such as "I like SSU because it gives me ideas which I try", "I watch SSU because it helps me to make decisions" and "I believe I learn new things about farming when I watch SSU" are the top reasons within this factor. Hence the first factor covers one aspect of TV edutainment, which is the educational part. The second factor for maize farmers is associated with the empathy felt by farmers when watching the programme with the farmers and their families. This second aspect identified has nothing to do with education nor entertainment but the farmer feeling engaged through sensitive aspects related to care and empathy with farmers appearing on the show. The third aspect relates to the fun/entertainment part of the programme, whereas the last factor highlights other part of the entertainment feature of the programme. This fourth factor touches on being entertained because the farmer finds the presenters likeable and because the programme is watched in a public place (i.e. with others).

\footnotetext{
${ }^{14}$ The Kaiser-Meyer-Olkin measure for maize and dairy were 0.82 indicating the convenience of conducting factor analysis.
} 
Table 4: Factor loadings for reasons to watch SSU TV edutainment -maize farmers Statements

Factor1 Factor2 Factor3 Factor4

I like Shamba Shape-Up because it gives me ideas which I try $\quad 0.82$

I watch Shamba Shape-Up because it helps me to make decisions

0.71

I believe I learn new things about farming when I watch Shamba shape up $\quad 0.71$

I watch SSU because I know I am going to get useful information 0.47

Shamba Shape-up makes me feel happy

0.47

I care about families shown in the Shamba Shape-Up TV programme

0.51

I get emotional/involved when I see the problems farmers face in the SSU TV programme

0.79

0.70

I identify with the problems farmers face in Shamba Shape-up TV programme

0.66

I always think of other farmers I know when I watch the Shamba Shape-Up programme

0.44

I like Shamba Shape-Up because it is fun to watch

I find useful that I can text or call Shamba Shape-UP to ask questions 
372 Regarding dairy farmers, three factors were identified to be behind watching SSU (Table 4).

373 In this case, farmer's decision to watch SSU is mainly due to the perceived usefulness of the

374 programme, the two aspects related to entertainment identified for the maize farms: “...it is

375 fun to watch" and the entertainment related to watching the programme with others in a

376 public place and finding the presenters likeable.

377 As for farmer's level of trust in sources of information, the farmer's reasons for watching

378 SSU were incorporated into the in the model as explanatory variables.

379 
Table 5: Factor loadings for reasons to watch SSU TV edutainment -dairy farmers

\begin{tabular}{|c|c|c|c|}
\hline Statements & Factor1 & Factor2 & Factor3 \\
\hline I like Shamba Shape-Up because it gives me ideas which I try & 0.73 & & \\
\hline I watch Shamba Shape-Up because it helps me to make decisions & 0.68 & & \\
\hline I believe I learn new things about farming when I watch Shamba shape up & 0.65 & & \\
\hline I watch SSU because I know I am going to get useful information & 0.59 & & \\
\hline I identify with the problems farmers face in Shamba Shape-up TV programme & 0.58 & & \\
\hline I care about families shown in the Shamba Shape-Up TV programme & 0.53 & & \\
\hline I get emotional/involved when I see the problems farmers face in the SSU TV programme & 0.53 & & \\
\hline I always think of other farmers I know when I watch the Shamba Shape-Up programme & 0.50 & & \\
\hline I like Shamba Shape-Up because it is fun to watch & & 0.75 & \\
\hline I find useful that I can text or call Shamba Shape-UP to ask questions & & 0.58 & \\
\hline Shamba Shape-up makes me feel happy & & 0.58 & \\
\hline I enjoy watching Shamba Shape-Up TV programme with others in a public place & & & 0.75 \\
\hline I watch Shamba Shape-Up mainly because I like the presenters & & & 0.75 \\
\hline
\end{tabular}


386 Results show that SSU viewers are more likely to make more changes in their agricultural practices than non SSU viewers (Table 6). Although the results apply to both maize and dairy farmers, it was found that SSU has a higher impact for dairy farmers. There are two reasons that may explain why dairy farmers are more likely to make changes used than maize farmers in their agricultural practices. The first reason is that dairy production may be seen as more of a business than maize farming. Whereas dairy production may be a product primarily oriented for sale, this may not be the case for maize. A growing demand for milk offers scope for wealth creation among small-scale farmers and poor remote households in Kenya. Indeed, effective participation in the production of milk for emerging lucrative markets is considered a supply-response to the potential for increments in household wealth among farmers in developing countries over time (Burke et al., 2007; Martínez-García et al., 2013; Omiti et al., 2009). Martínez-García et al. (2013) found that small-scale dairy systems play an important role in providing income, employment and nutrition in the highlands of central Mexico. Also, evidence drawn from household surveys suggest that small holder farmers in Kenya do not often participate in staple food markets and when they do, their market share is low. Mather et al. (2013) found that only $43 \%$ of rural households were net sellers of maize and that sales were highly concentrated among a few sellers. The second reason has to do with dairy being a more recent enterprise than maize, so farmers may be still learning and expanding dairy production.

Results also show that farmer's reasons for watching SSU may affect farmer's probability of implementing agricultural practices shown in the SSU TV programme. More specifically, for maize farmers we find that when a farmer's reason for watching SSU is purely for entertainment and watching SSU with friends the probability of implementing agricultural practices shown in SSU is less than when this is not the reason for watching SSU. 
410 Regarding the effect of farmer's characteristics on their decision to implement a relatively

411 large number of practices, farmer's level of education was found to be an important factor determining change in the agricultural practices implemented, with more educated farmers being more likely to implement a relatively larger number of practices. This is in line with earlier literature on education which finds education as a factor in 'innovation' and technology adoption (Baltenweck et al., 2003; Nicholson et al., 1999; Staal et al., 2002). A Farmer's age was also found to be a significant factor, with older farmers applying relatively higher number of agricultural practices shown in SSU than younger farmers. The literature offers a mixed picture regarding the relationship of age and innovation. Whereas some literature notes that younger farmers are more dynamic, energetic, keen to change (EspinozaOrtega et al. 2007); on the other hand, some other literature finds no relationship between age and innovation (Abebaw and Haile, 2013b) and some finds a positive relationship that older, more experienced farmers are more likely to have secure access to land, access to money to invest in new inputs . Thus, Staal et al. (2002) found that farming experience was positively related to uptake of dairy cattle. We found no statistically significant differences in the number of agricultural practices applied in terms of gender. Regarding household characteristics studied, results suggest that relatively medium/high income level households are more likely to implement changes to their current agricultural practices (i.e. a relatively high number of agricultural practices) than poor income households. Wealthier households have more opportunity of making changes than poorer households or households with liquidity or capital constraints (Lapar and Ehui, 2004). Other household characteristic considered, household female ratio and household children ratio, had no significant impact on the probability of applying relatively high numbers of practices. Number of cows was found to be negatively associated with implementing a relatively large number of agricultural practices shown on SSU TV programme (i.e. the bigger the number of cows the less likely it 
is that dairy farmers will apply a large number of practices). Farmers with many cows may

436 be relatively limited to make the changes proposed (e.g. increase the number of cows, make

437

438

439

440

441

442

443

444

445

446

447

448

449

450

451

452

453 1

and feed hay). However, this association was found not to be statistically significant.

Farmers' general views on farming were found to be an important factor leading to change, particularly for dairy farmers. Those farmers who are relatively more positive about trying new things, enjoying farming, seeing farming as a business and a way to feed their family (group F1) were found to be more likely to implement more practices than those who tend to think more that their farm is too small to care about making changes; find relatively more difficulties in knowing who to contact about inputs and materials; farmers who are relatively more sceptical that new technologies will work (group F2). Finally, the level of trust on sources of income was found to have some influence on change. For maize farmers it was found that the higher the level of trust is in traditional sources (mainly farmer's close social network of friends and family) the less likely it is that farmers will implement a relatively large number of changes. On the other hand, for dairy farmers the more trust they have in sources of information that come to the farm to provide advice, such as agricultural extension officers and NGOs, the more likely it is that they will apply a large number of changes.

Table 6: Determinants of farmer's applying a relatively large number of practices on maize and dairy production

\begin{tabular}{lcccc} 
& \multicolumn{2}{c}{ Maize } & \multicolumn{2}{c}{ Dairy } \\
\hline & Coeff. & z-statistic & Coeff. & z-statistic \\
\hline Constant & -0.631 & -1.59 & $-1.844^{* * *}$ & -3.45 \\
SSU viewers & $0.160^{* *}$ & 1.98 & $0.438^{* * * *}$ & 3.87 \\
F1 - Education/Usefulness & 0.020 & 0.38 & -0.031 & -0.47 \\
(empathy - dairy) & & & & \\
F2 - Empathy & 0.025 & 0.46 & - & - \\
F3 - Entertainment/fun & 0.033 & 0.68 & -0.011 & -0.15 \\
F4 - Entertainment/friends & $-0.184^{* * *}$ & -3.61 & -0.047 & -0.66 \\
Media_trust (TV news, Magazine) & 0.008 & 0.21 & $0.119 * *$ & 2.14 \\
External1_trust (Agro- & 0.012 & 0.37 & 0.043 & 0.87 \\
dealers/shopkeeper/agrivet) & & & &
\end{tabular}




\begin{tabular}{lcccc} 
External2_trust (NGO/Agriculture & -0.022 & -0.65 & $0.093^{*}$ & 1.78 \\
extension officer) & & & & \\
Traditional_trust (friends/family) & $-0.078^{* *}$ & -2.25 & 0.031 & 0.65 \\
Farmer's Age & $0.005^{*}$ & 1.76 & $0.010^{* * *}$ & 2.55 \\
Gender & -0.060 & 0.82 & 0.028 & 0.27 \\
Primary education & $0.308^{*}$ & 1.89 & $0.509^{* *}$ & 2.21 \\
Secondary education & $0.410^{* *}$ & 2.38 & $0.569^{* *}$ & 2.37 \\
College after & $0.638^{* * *}$ & 3.29 & $0.640^{* *}$ & 2.42 \\
secondary/University & & & & \\
Cluster F1 (farming as a business, & 0.083 & 1.14 & $0.198^{*}$ & 1.95 \\
enjoying farming) & & & & \\
HH female ratio & -0.253 & -1.43 & 0.054 & 0.21 \\
HH children ratio & 0.208 & 1.21 & 0.026 & 0.11 \\
Cropland area/number of cows & 0.008 & 0.49 & -0.028 & -1.03 \\
Normal PPI & $0.284 * *$ & 2.56 & $0.466^{* *}$ & 2.49 \\
High PPI & 0.150 & 1.07 & $0.687 * * *$ & 3.16 \\
\hline$\rho$ & 0.067 & 0.65 & -0.202 & -1.38 \\
Log-likelihood (Probit model) & -1648.452 & & -489.940 & \\
Log likelihood (SEM) & -1648.239 & & -874.595 & \\
$N$ & 1436 & & 806 & \\
\hline
\end{tabular}

454

455

Marginal effects on the probability of implementing a number of agricultural practices in

the last 12 months/season for maize and dairy farmers

458

Table 7 presents the marginal effects for both models, maize and dairy. The marginal effects

for dummy variables (SSU viewers, Gender, Primary education, Secondary education,

460

College after secondary/University, Cluster F1, Normal PPI and High PPI) measures the

461

effect of a change in the dummy variable, from 0 to 1 , on the probability of implementing

462

agricultural practices in the last 12 months/season.

463

The estimated probability of implementing a relative large number of agricultural practices

for the average maize and dairy farmer in the sample (i.e. taking the average values in the

sample of the explanatory variables) is $52 \%$ and $38 \%$, respectively. However, there are

differences in these probabilities between SSU watchers and non-watchers holding

everything else constant. The models estimate a 6 and 16 points increase in the probability of implementing a relative high number of agricultural in the case that maize and dairy farmers 
SSU is that maize farmers like the presenters or want to watch the programme in a public

471 place then there would be no difference in the probability of implementing agricultural

472 changes between SSU viewers and non-viewers.

473 The difference between educated and non-educated farmers in the increase in the probability

474 of implementing a relatively large agricultural changes varies between $12 \%(19 \%)$ and $24 \%$

$475(25 \%)$ for maize (dairy) farmers depending on their level of education.

476

477

478

Table 7. Marginal effects of variables on the probability of implementing a number of agricultural practices in the last 12 months/season for maize and dairy farmers

\begin{tabular}{lcccc} 
& \multicolumn{2}{c}{ Maize } & \multicolumn{2}{c}{ Dairy } \\
\hline & dy/dx & z-statistic & dy/dx & z-statistic \\
\hline SSU viewers & $0.064^{* *}$ & 1.98 & $0.164^{* * *}$ & 3.98 \\
F1 - Education/Usefulness & 0.008 & 0.38 & -0.012 & -0.47 \\
(empathy - dairy) & & & & \\
F2 - Empathy & 0.010 & 0.46 & - & - \\
F3 - Entertainment/fun & 0.013 & 0.68 & -0.004 & -0.15 \\
F4 - Entertainment/friends & $-0.073^{* * *}$ & -3.61 & -0.018 & -0.66 \\
Media_trust (TV news, magazine) & 0.003 & 0.21 & $0.045^{* *}$ & 2.14 \\
External1_trust (Agro- & 0.005 & 0.37 & 0.017 & 0.87 \\
dealers/shopkeeper/agrivet) & & & & \\
External2_trust (NGO/Agriculture & -0.009 & -0.65 & $0.036^{*}$ & 1.78 \\
extension officer) & & & & \\
Traditional_trust (friends/family) & $-0.031^{* *}$ & -2.25 & 0.010 & 0.55 \\
Farmer's Age & $0.002^{*}$ & 1.76 & $0.004^{* * *}$ & 2.55 \\
Gender & -0.024 & 0.82 & 0.011 & 0.27 \\
Primary education & $0.122^{*}$ & 1.90 & $0.194 * *$ & 2.24 \\
Secondary education & $0.161^{* *}$ & 2.43 & $0.219^{* *}$ & 2.39 \\
College after & $0.241^{* * *}$ & 3.61 & $0.250^{* * *}$ & 2.47 \\
secondary/University & & & & \\
Cluster F1 (farming as a business, & 0.033 & 1.14 & $0.076^{*}$ & 1.95 \\
enjoying farming) & & & & \\
HH female ratio & -0.101 & -1.43 & 0.020 & 0.21 \\
HH children ratio & 0.083 & 1.21 & 0.010 & 0.11 \\
Cropland area/number of cows & -0.003 & -0.49 & $-0.011^{* *}$ & -1.03 \\
Normal PPI & $0.113^{* * *}$ & 2.58 & $0.174^{* *}$ & 2.58 \\
High PPI & 0.059 & 1.08 & $0.266^{* * *}$ & 3.22 \\
\hline
\end{tabular}


The results shown above show that edutainment programme SSU is correlated with the probability of implementing a relatively large number of agricultural practices. However, we also investigated whether particular practices differ in terms of being more (or less) popular than others and what may be influencing such differences in the number of farmers implementing these practices. For this, we analysed the relationships between SSU viewership and the implementation of individual practices. We only analyse those practices for which at least 80 farmers (i.e. $6 \%$ of the sample for maize and $10 \%$ for dairy) answered that they implemented the particular agricultural practice. Tables 8 and 9 show the coefficient estimates for models explaining the probability of implementing individual agricultural practices by maize and dairy farmers, respectively (Marginal effect tables can be found in the appendices A.3 and A.4).

Results for maize show that SSU viewership is positively associated with implementing agricultural practices such as applying fertilizer at planting, applying fertilizer mixed with manure at planting, purchasing maize seed from agro-dealer shop, purchasing packed seeds for intercropping from a shop/agro dealer, applying top dressing fertiliser and using actellic in the stored maize. Interestingly it was also found that planting maize at $2.5 \mathrm{feet} / 75 \mathrm{~cm}$ between rows and 1 foot $/ 30 \mathrm{~cm}$ between plants was negatively associated with being a SSU viewer. This could be due to some particular difficulties found by the farmer in the TV programme. We found that the farmers' stated reasons for watching SSU explain some of the heterogeneity within the probability of SSU viewers of making specific changes to their agricultural practices. Being empathetic with farmers appearing on the TV programme is associated with farmer's decision to implement the agricultural practices shown on SSU. It was positively associated with farmer's decisions to apply fertiliser at planting and planting a 
508

509

510

511 less keen to implement this practice. We also found that for most practices those viewers that

512 enjoyed watching SSU mainly because of having entertaining time with friends tended to be

513 less keen to apply the practices shown in the programme than those who watch the program

514 for other reasons. Watching SSU for educational purposes was positively related to the

515 probability of purchasing packed seeds for intercropping from a shop/agro dealer (if the

516 reason for watching SSU is educational) and to the probability of planting maize at 2.5

517 feet $/ 75 \mathrm{~cm}$ between rows and 1 foot $/ 30 \mathrm{~cm}$ between plants. Watching SSU for fun or with

518 friends was negatively associated to the probability of implementing most of the agricultural

519 practices considered. It is worth noting that we also found differences in the associations

520 between farmer and household's characteristics, farmer's views on farming and farmer's trust

521 on sources of influence. 


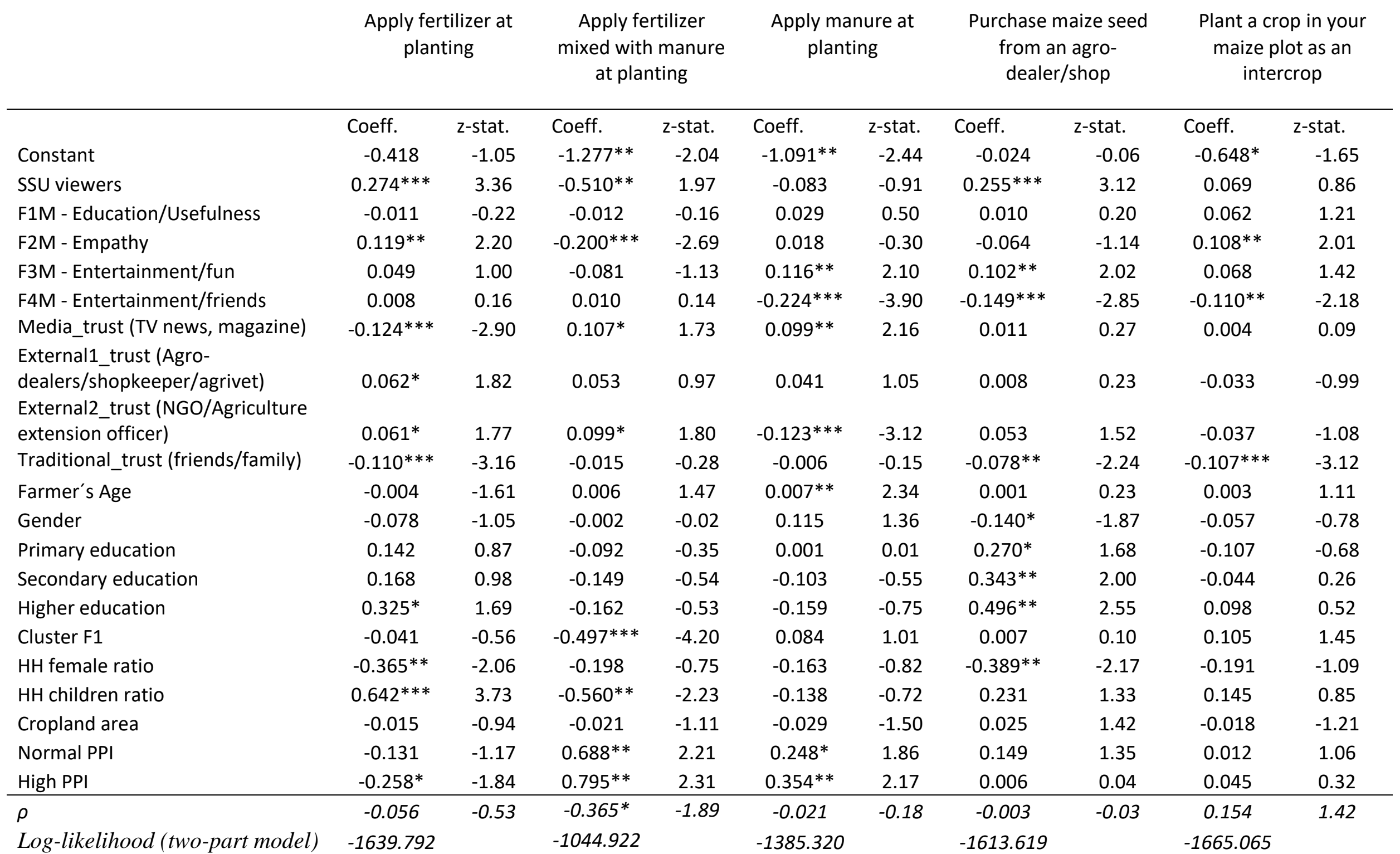


Table 8 (continued). Determinants of maize farmers' probability of implementing agricultural practices

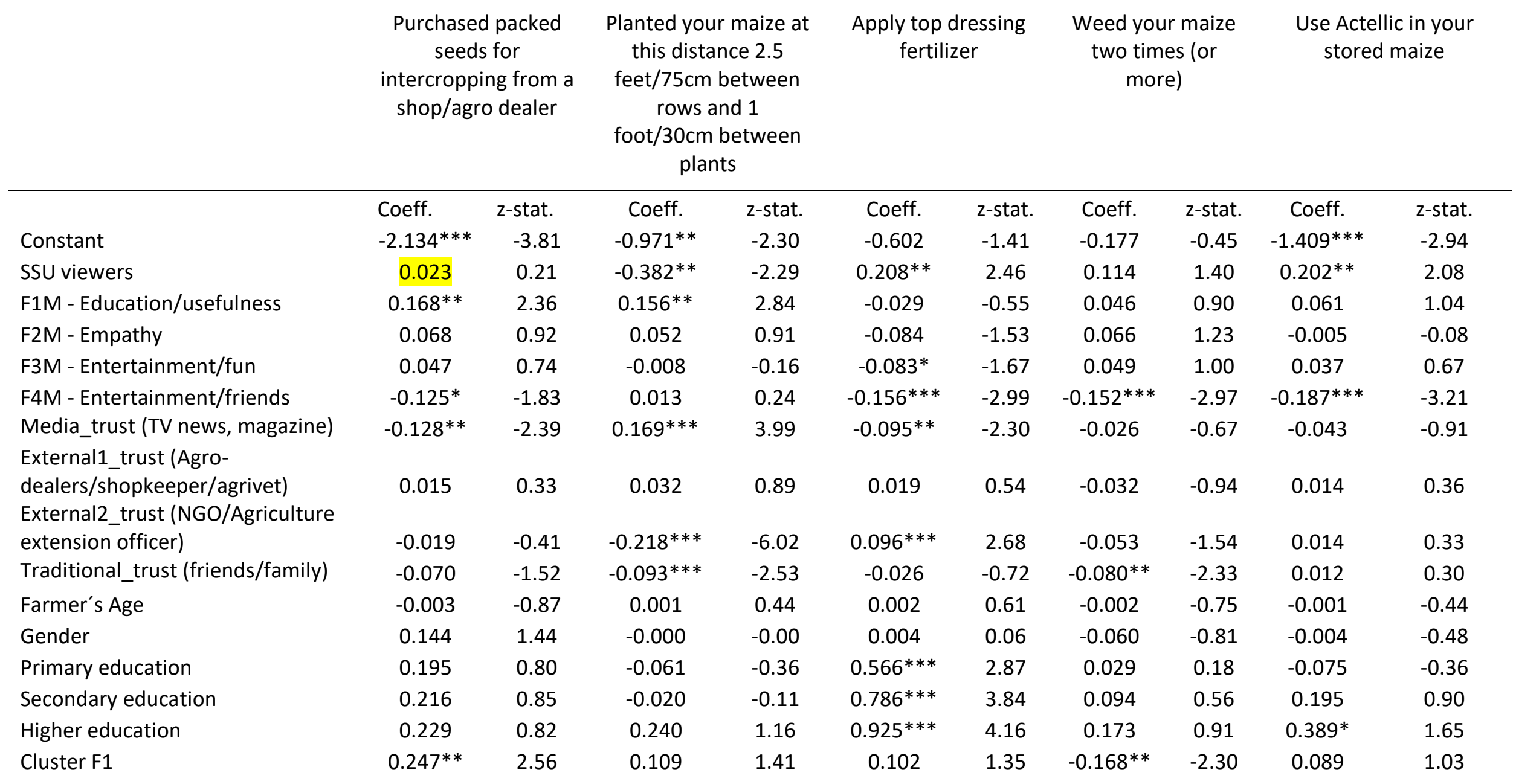




\begin{tabular}{|c|c|c|c|c|c|c|c|c|c|c|}
\hline $\mathrm{HH}$ female ratio & -0.274 & -1.17 & -0.305 & -1.61 & -0.202 & -1.08 & -0.211 & -1.20 & -0.268 & -1.24 \\
\hline $\mathrm{HH}$ children ratio & -0.109 & -0.47 & 0.192 & 1.04 & 0.329 & 1.83 & 0.003 & 0.02 & 0.333 & 1.62 \\
\hline Normal PPI & 0.230 & 1.41 & 0.004 & 0.03 & 0.072 & 0.61 & 0.075 & 0.68 & $0.327 * *$ & 2.19 \\
\hline$\rho$ & -0.246 & -1.61 & $-0.219 * *$ & 1.97 & 0.045 & 0.41 & 0.150 & 1.45 & -0.091 & -0.69 \\
\hline Log-likelihood (two-part model) & -1160.041 & & -1504.814 & & -1566.300 & & -1652.620 & & -1318.004 & \\
\hline Log likelihood (SEM) & -1158.688 & & -1502.853 & & -1566.214 & & -1651.567 & & -1317.178 & \\
\hline
\end{tabular}


534 Regarding results for dairy farmers results show that SSU viewers are keener to implement

535 certain practices shown in the edutainment programme than non-SSU viewers (see table 9;

536 marginal effects can be found in the appendix). These practices are increasing the area of

537 Napier grass, feeding cows using chopped Napier grass and purchasing supplemented feeds

538 or salt licks. As in maize production, SSU viewers who watch the programme for

539 entertainment tend to be less keen on increasing the area of Napier grass and feeding cows

540 using chopped Napier grass. If the reason for watching the TV programme is for

541 educational/usefulness purposes or empathy with the farmers, the probability of treating for

542 mastitis increases. Again, as in the case for maize farmers we also found heterogeneity

543 regarding the effect of other drivers and the probability of implementing agricultural changes

544 between agricultural practices.

545 To summarise, although we find that overall SSU positively affects the probability of

546 implementing a greater number of agricultural practices related to maize and dairy

547 production, this effect is not homogeneously found across the practices shown in the

548 edutainment program. Thus, holding everything constant maize farmers who are SSU viewers

549 are more likely to apply fertiliser at planting (+11\%), apply fertilizer mixed with manure at

550 planting (+8\%), purchase maize seed from a agro-dealer/shop (+7\%); apply top dressing

551 fertiliser $(+8 \%)$ and use actellic in their stored maize $(+5 \%)$ than farmers who do not watch

552 SSU. However, these increases are moderated by SSU viewers' reasons for watching SSU.

553 For example, the probability of applying fertiliser at planting increases by $5 \%$ if farmers

554 show empathy with farmers appearing in the programme. Regarding agricultural practices

555 relevant for dairy farmers watching SSU holding everything constant dairy farmers who are

556 SSU viewers are more likely to increase the area of Napier grass $(+6 \%)$, feed cows using

557 chopped Napier grass (9\%) and purchase supplement feeds or salt licks (+9\%). 


\begin{tabular}{|c|c|c|c|c|c|c|c|c|}
\hline & \multicolumn{2}{|c|}{$\begin{array}{l}\text { Increase the size } \\
\text { of your dairy herd }\end{array}$} & \multicolumn{2}{|c|}{$\begin{array}{l}\text { Increase the area } \\
\text { of Napier Grass }\end{array}$} & \multicolumn{2}{|c|}{$\begin{array}{c}\text { Feed cows using } \\
\text { chopped Napier } \\
\text { Grass }\end{array}$} & \multicolumn{2}{|c|}{$\begin{array}{l}\text { Spray dairy cows } \\
\text { for ticks or lice }\end{array}$} \\
\hline & Coeff. & $\begin{array}{l}\text { z- } \\
\text { stat. }\end{array}$ & Coeff. & $\begin{array}{l}\text { z- } \\
\text { stat. }\end{array}$ & Coeff. & z-stat. & Coeff. & z-stat. \\
\hline Constant & $-2.158 * * *$ & -3.63 & $-2.522 * * *$ & -3.84 & $-1.233^{* * *}$ & -2.34 & 0.517 & 0.95 \\
\hline SSU viewers & 0.188 & 1.42 & $0.274^{* *}$ & 1.99 & $0.229 * *$ & 2.04 & 0.047 & 0.39 \\
\hline F1D - Education/Usefulness/empathy & 0.044 & 0.56 & $0.153^{*}$ & 1.95 & -0.024 & -0.35 & -0.052 & -0.69 \\
\hline F2D - Entertainment/fun & 0.068 & 0.87 & 0.010 & 0.13 & -0.091 & -1.29 & -0.012 & -0.15 \\
\hline F3D - Entertainment/friends & -0.035 & -0.42 & $-0.224 * *$ & -2.58 & $-0.156^{* *}$ & -2.17 & -0.087 & -1.08 \\
\hline Media_trust (TV news, magazines) & -0.021 & -0.32 & -0.063 & -0.93 & $0.140^{* *}$ & 2.53 & $0.187^{* * *}$ & 3.15 \\
\hline External1_trust (Agrodealers, agrivet) & -0.072 & -1.30 & 0.032 & 0.53 & $0.092^{*}$ & 1.86 & 0.064 & 1.25 \\
\hline External2_trust (Ag. Extension officer, NGO) & $-0.094 *$ & -1.65 & -0.080 & -1.30 & -0.009 & -0.18 & $0.259 * * *$ & 4.78 \\
\hline Traditional_trust (friends, family) & 0.047 & 0.86 & 0.056 & 0.96 & 0.041 & 0.86 & -0.023 & -0.45 \\
\hline Farmer's Age & 0.004 & 0.90 & 0.006 & 1.38 & $0.013 * * *$ & 3.35 & -0.001 & -0.16 \\
\hline Gender & -0.083 & -0.70 & 0.053 & 0.42 & 0.110 & 1.06 & -0.083 & -0.76 \\
\hline Primary education & 0.256 & 0.94 & 0.460 & 1.47 & $0.558 * *$ & 2.50 & $0.380^{*}$ & 1.80 \\
\hline Secondary education & 0.339 & 1.20 & $0.669 * *$ & 2.07 & $0.614 * * *$ & 2.63 & 0.180 & 0.80 \\
\hline Higher education & $0.606^{* *}$ & 1.97 & $0.753 * *$ & 2.17 & $0.547 * *$ & 2.11 & 0.167 & 0.65 \\
\hline Cluster F1 & 0.025 & 0.21 & -0.106 & -0.86 & $0.183^{*}$ & 1.80 & -0.027 & -0.25 \\
\hline HH female ratio & -0.077 & -0.27 & -0.052 & -0.17 & -0.115 & -0.45 & -0.031 & -0.12 \\
\hline $\mathrm{HH}$ children ratio & $0.592^{* *}$ & 2.18 & 0.079 & 0.28 & -0.019 & -0.08 & 0.126 & 0.51 \\
\hline Number of cows & $0.068 * * *$ & 4.20 & -0.011 & -0.43 & $-0.152^{* * *}$ & -4.29 & 0.009 & 0.49 \\
\hline Normal PPI & 0.071 & 0.37 & $0.600 * *$ & 2.30 & $0.756^{* * *}$ & 4.02 & $0.289^{*}$ & 1.76 \\
\hline High PPI & 0.017 & 0.07 & 0.472 & 1.61 & $0.943 * * *$ & 4.29 & $0.440 * *$ & 2.12 \\
\hline$P$ & -0.033 & -0.85 & -0.240 & -0.17 & -0.229 & -1.64 & 0.032 & 0.84 \\
\hline
\end{tabular}




\begin{tabular}{lcccc} 
Log-likelihood (two-part model) & -739.831 & -698.654 & -877.733 & -813.426 \\
Log likelihood (SEM) & -739.813 & -699.996 & -876.311 & -813.637 \\
N & 805 & 805 & 805 & 805 \\
\hline
\end{tabular}

Table 9 (continued). Determinants of dairy farmers' probability of implementing agricultural practices

\begin{tabular}{|c|c|c|c|c|c|c|c|c|}
\hline & \multicolumn{2}{|c|}{$\begin{array}{l}\text { Deworm your } \\
\text { dairy cows }\end{array}$} & \multicolumn{2}{|c|}{ Treat for mastitis } & \multicolumn{2}{|c|}{$\begin{array}{c}\text { Purchase } \\
\text { supplement feeds or } \\
\text { salt licks }\end{array}$} & \multicolumn{2}{|c|}{$\begin{array}{c}\text { Ensure cows have } \\
\text { enough water all } \\
\text { day }\end{array}$} \\
\hline Constant & $\begin{array}{l}\text { Coeff. } \\
1.283^{* *}\end{array}$ & $\begin{array}{l}\text { z-stat. } \\
2.04\end{array}$ & $\begin{array}{c}\text { Coeff. } \\
-2.726^{* * *}\end{array}$ & $\begin{array}{l}\text { z- } \\
\text { stat. } \\
-4.13\end{array}$ & $\begin{array}{l}\text { Coeff. } \\
0.814\end{array}$ & $\begin{array}{c}\text { z-stat. } \\
1.54\end{array}$ & $\begin{array}{c}\text { Coeff. } \\
-1.398^{* * *}\end{array}$ & $\begin{array}{l}\text { z- } \\
\text { stat. } \\
-2.68\end{array}$ \\
\hline SSU viewers & 0.195 & 1.42 & 0.122 & 0.89 & $0.238 * *$ & 2.08 & 0.166 & 1.47 \\
\hline F1D - Education/Usefulness/empathy & -0.131 & -1.49 & $0.160 * *$ & 2.01 & $-0.140^{*}$ & -1.93 & -0.094 & -1.37 \\
\hline F2D - Entertainment/fun & -0.059 & -0.65 & -0.001 & -0.01 & $-0.143^{*}$ & -1.94 & -0.055 & -0.79 \\
\hline F3D - Entertainment/friends & 0.061 & 0.67 & -0.114 & -1.37 & 0.03 & 0.40 & 0.118 & 1.62 \\
\hline Media_trust (TV news, magazines) & $0.217 * * *$ & 3.26 & 0.088 & 1.32 & $0.184^{* * *}$ & 3.27 & $0.163 * * *$ & 2.96 \\
\hline External1_trust (Agrodealers, agrivet) & $0.112 *$ & 1.95 & 0.090 & 1.52 & -0.039 & -0.81 & $0.125^{* *}$ & 2.57 \\
\hline External2_trust (Ag. Extension officer, NGO) & $0.306^{* * *}$ & 5.15 & 0.049 & 0.81 & $0.098^{*}$ & 1.90 & $0.161^{* * *}$ & 3.18 \\
\hline Traditional_trust (friends, family) & $0.094 *$ & 1.71 & -0.033 & -0.60 & 0.065 & 1.35 & $0.125^{* * *}$ & 2.64 \\
\hline Farmer's Age & 0.003 & 0.62 & 0.005 & 1.13 & -0.001 & -0.34 & $0.009 * *$ & 2.3 \\
\hline Gender & -0.146 & -1.19 & 0.086 & 0.69 & 0.087 & 0.83 & -0.023 & -0.22 \\
\hline Primary education & 0.056 & 0.22 & 0.453 & 1.42 & 0.086 & 0.42 & $0.663 * * *$ & 3.08 \\
\hline Secondary education & -0.188 & -0.70 & $0.604 *$ & 1.84 & 0.019 & 0.09 & $0.542^{* *}$ & 2.4 \\
\hline Higher education & -0.122 & -0.40 & $0.675^{*}$ & 1.92 & 0.194 & 0.77 & $0.435^{*}$ & 1.73 \\
\hline
\end{tabular}




\begin{tabular}{lcccccccc} 
Cluster F1 & $0.437^{* *}$ & 3.57 & 0.110 & 0.91 & $0.370^{* * *}$ & 3.57 & $0.172^{*}$ & 1.69 \\
HH female ratio & -0.124 & -0.41 & 0.005 & 0.02 & -0.304 & -1.17 & 0.169 & 0.65 \\
HH children ratio & -0.273 & -0.97 & 0.139 & 0.49 & -0.188 & -0.78 & 0.024 & 0.10 \\
Number of cows & -0.015 & -0.69 & 0.022 & 1.13 & -0.035 & -1.49 & -0.046 & -1.66 \\
Normal PPI & -0.020 & -0.11 & $0.504^{* *}$ & 1.97 & 0.191 & 1.21 & $0.512^{* * *}$ & 3.08 \\
High PPI & 0.143 & 0.62 & 0.414 & 1.43 & $0.518^{* * *}$ & 2.60 & $0.921^{* * *}$ & 4.51 \\
\hline$P$ & 0.218 & 0.20 & -0.274 & -0.13 & -0.093 & -0.53 & 0.061 & 0.44 \\
Log-likelihood (two-part model) & -715.285 & & -708.319 & & -858.176 & & -878.401 & -878.302 \\
Log likelihood (SEM) & -714.480 & & -707.106 & & -857.973 & & & \\
N & 805 & & 805 & & 805 & & 805 \\
\hline
\end{tabular}

566 


\section{Conclusions and policy implications}

569 Edutainment TV programs aiming at farmers in developing countries can be a way of succeeding in having a more productive and sustainable agriculture in developing countries that contributes to achieving Sustainable Development Goals of no poverty and zero hunger. The use of edutainment programmes has been shown that can be a powerful tool in encouraging farmers to make changes in their agricultural practices. We found that the SSU TV edutainment programme contributes to helping farmers making changes in their agricultural practices by showing real life examples. However, changing the agricultural practices shown on edutainment depends on the type of agricultural output produced and the associated difficulty of making the changes. Thus, we found that relatively simple changes in maize production practices are more likely to be implemented as a consequence of watching TV edutainment programmes than those practices that are relatively more complex. Individual characteristics of the farmers such as their reasons behind watching the TV edutainment programme, their level of education and the level of trust on sources of information such as family and friends also shape the likelihood of changing their agricultural practices. Since not all agricultural practices shown in edutainment programmes may have the same level of acceptance care should be taken by the edutainment TV programme in selecting agricultural practices that are realistic for targeted farmers to implement.

Policy implications of our findings are that edutainment TV should be considered and supported as a way to introduce changes in specific agricultural practices. Organisations and governments could contribute by supporting edutainment TV as a viable channel to educate farmers in agricultural practices that are sustainable, protect the environment, contribute to climate change adaptation and mitigation and contribute to reducing poverty, hunger and malnutrition by increasing productivity, income and food security. Thus, support by governments could be through collaboration with private enterprises in these initiatives (e.g. 
593

594

595

596 It is worth pointing out that parallel information to the one presented by SSU could have been

597 presented through radio and other TV programmes which could have reinforced SSU

598

599

600

601

602

603

604

605

606

607

608

609

610

providing information on the key agricultural practices supported by the government and/or providing funding) or providing edutainment TV through national channels. messages. Also, in this analysis we have used a binary viewership indicator. Using information on the level of viewership (e.g. always, sometimes, a few episodes, never) could have provided a more disaggregated analysis in terms of by level of viewership

Acknowledgements This paper is based on an independent evaluation of Shamba Shape Up carried out by the University of Reading, alongside partners from Research Guide Africa, Wageningen University, Howard and Crowe PLC and Africa Centre for Applied Research. This evaluation took place in 2014 and was funded by Africa Enterprise Challenge Fund. The authors would like to acknowledge the role played in the research design by Marlene Roefs (Wageningen) and the research design and data collection by Carol Matika (Research Guide Africa). 


\section{References}

612 Abate, G.T., Rashid, S., Borzaga, C., Getnet, K., 2016. Rural Finance and Agricultural Technology Adoption in Ethiopia: Does the Institutional Design of Lending Organizations Matter? World Dev. 84, 235-253. https://doi.org/10.1016/J.WORLDDEV.2016.03.003

615

616

617

618

619

620

621

622

Abebaw, D., Haile, M.G., 2013a. The impact of cooperatives on agricultural technology adoption: Empirical evidence from Ethiopia. Food Policy 38, 82-91. https://doi.org/10.1016/J.FOODPOL.2012.10.003

Abebaw, D., Haile, M.G., 2013b. The impact of cooperatives on agricultural technology adoption: Empirical evidence from Ethiopia. Food Policy 38, 82-91. https://doi.org/10.1016/J.FOODPOL.2012.10.003

Ajzen, I., 1991. The theory of planned behavior. Organ. Behav. Hum. Decis. Process. 50, 179-211. https://doi.org/10.1016/0749-5978(91)90020-T

Ajzen, I., 1987. Attitudes, Traits, and Actions: Dispositional Prediction of Behavior in Personality and Social Psychology. Adv. Exp. Soc. Psychol. 20, 1-63. https://doi.org/10.1016/S00652601(08)60411-6

Ajzen, I., 1985. From Intentions to Actions: A Theory of Planned Behavior, in: Kuhl, J., Beckmann, J. (Eds.), Action Control. Springer, Berlin, Heidelberg, pp. 11-39.

Baltenweck, I., Staal, S., Ibrahim, M.N.M., Herrero, M., Holfman, F., Manyong, V., Jabbar, M., Patil, B.R., Thornton, P.K., Williams, T., Waithaka, M.M., De Wolf, T., 2003. Crop-livestock intensification and interaction across three continents. Final Project Report. Addis Ababa, Ethiopia.

Boucher, S.R., Carter, M.R., Guirkinger, C., 2008. Risk Rationing and Wealth Effects in Credit Markets: Theory and Implications for Agricultural Development. Am. J. Agric. Econ. 90, 409-423. 
Burke, W.J., Jayne, T.S., Freeman, H.A., Kristjanson, P., 2007. Factors associated with farm households' movement into and out of poverty in Kenya: The rising importance of livestock,

Cappellari, L., Jenkins, S.P., 2003. Multivariate Probit Regression using Simulated Maximum

Caraher, M., Lange, T., Dixon, P., 2009. The Influence of TV and Celebrity Chefs on Public Attitudes and Behavior Among the English Public. J. Study Food Soc. https://doi.org/10.2752/152897900786690805

Clarkson, G., Garforth, C., Dorward, P., Mose, G., Barahona, C., Areal, F., Dove, M., 2018. Can the TV makeover format of edutainment lead to widespread changes in farmer behaviour and influence innovation systems? Shamba Shape Up in Kenya. Land use policy 76. https://doi.org/10.1016/j.landusepol.2018.05.011

Colace, F., De Santo, M., Pietrosanto, A., Troiano, A., 2006. Work in progress: Bayesian networks for edutainment, in: Proceedings - Frontiers in Education Conference, FIE. https://doi.org/10.1109/FIE.2006.322573

Creighton, M.R., 2007. "Edutaining" Children: Consumer and Gender Socialization in Japanese Marketing. Ethnology. https://doi.org/10.2307/3773973

Davis, F.D., 1989. Perceived Usefulness, Perceived Ease of Use, and User Acceptance of Information Technology. MIS Q. 13, 319-340. https://doi.org/10.2307/249008

Davis, F.D., Bagozzi, R.P., Warshaw, P.R., 1989. User Acceptance of Computer Technology: A Comparison of Two Theoretical Models. Manage. Sci. 35, 982-1003. 
De Backer, C.J.S., Hudders, L., 2016. Look who's cooking. Investigating the relationship between watching educational and edutainment TV cooking shows, eating habits and everyday cooking practices among men and women in Belgium. Appetite. https://doi.org/10.1016/j.appet.2015.10.016

de Fossard, E., 2008. Using Edu-Tainment for distance education in community work. Sage Publishing.

DEFRA, 2019. Agriculture in the United Kingdom 2018. DEFRA.

Dway, N.S., Soonthornworasiri, N., Jandee, K., Lawpoolsri, S., Pan-Ngum, W., Sinthuvanich, D., Kaewkungwal, J., 2015. Effects of edutainment on knowledge and perceptions of Lisu mothers about the immunisation of their children. Health Educ. J. 75, 131-143. https://doi.org/10.1177/0017896915569086

Espinoza-Ortega, A., Espinoza-Ayala, E., Bastida-López, J., Castañeda-Martínez, T., Arriaga-Jordán, C.M., 2007. SMALL-SCALE DAIRY FARMING IN THE HIGHLANDS OF CENTRAL MEXICO: TECHNICAL, ECONOMIC AND SOCIAL ASPECTS AND THEIR IMPACT ON POVERTY. Exp. Agric. 43, 241-256. https://doi.org/10.1017/S0014479706004613

FAO, OCDE, 2018. Food security and nutrition: challenges for agriculture and the hidden potential of soil.

Feenstra, F., Muzellec, L., de Faultrier, B., Boulay, J., 2015. Edutainment experiences for children in retail stores, from a child's perspective. J. Retail. Consum. Serv. 26, 47-56. https://doi.org/10.1016/J.JRETCONSER.2015.05.004

Fishbein, M.E., 1967. Readings in attitude theory and measurement.

Flora, J.A., Saphir, M., Lappé, M., Roser-Renouf, C., Maibach, E.W., Leiserowitz, A.A., 2014. Evaluation of a national high school entertainment education program: The Alliance for Climate 
681

682

683

684

685

686

687

688

689

690

691

692

693

694

695

696

697

698

699

700

701

702

Forster, M., Allem, J.-P., Mendez, N., Qazi, Y., Unger, J.B., 2016. Evaluation of a telenovela designed to improve knowledge and behavioral intentions among Hispanic patients with end-stage renal disease in Southern California. Ethn. Health 21, 58-70. https://doi.org/10.1080/13557858.2015.1007119

Jana, M., Letsela, L., Scheepers, E., Weiner, R., 2015. Understanding the Role of the OneLove Campaign in Facilitating Drivers of Social and Behavioral Change in Southern Africa: A Qualitative Evaluation. J. Health Commun. 20, 252-258. https://doi.org/10.1080/10810730.2014.925014

Jenkins, A.L., Tavengwa, N. V, Chasekwa, B., Chatora, K., Taruberekera, N., Mushayi, W., Madzima, R.C., Mbuya, M.N.N., 2012. Addressing social barriers and closing the gender knowledge gap: exposure to road shows is associated with more knowledge and more positive beliefs, attitudes and social norms regarding exclusive breastfeeding in rural Zimbabwe. Matern. Child Nutr. 8, 459-470. https://doi.org/10.1111/j.1740-8709.2011.00325.x

Lapar, M.L.A., Ehui, S.K., 2004. Factors affecting adoption of dual-purpose forages in the Philippine uplands. Agric. Syst. 81, 95-114. https://doi.org/10.1016/J.AGSY.2003.09.003

Martínez-García, C.G., Dorward, P., Rehman, T., 2013. Factors influencing adoption of improved grassland management by small-scale dairy farmers in central Mexico and the implications for future research on smallholder adoption in developing countries. Livest. Sci. 152, 228-238. https://doi.org/10.1016/J.LIVSCI.2012.10.007

Mather, D., Boughton, D., Jayne, T.S., 2013. Explaining smallholder maize marketing in southern and eastern Africa: The roles of market access, technology and household resource endowments. Food Policy 43, 248-266. https://doi.org/10.1016/J.FOODPOL.2013.09.008 
Nicholson, C.F., Thornton, P.K., Mohammed, L., Muninga, R.W., Mwamachi, D.M., Elbasha, E.H., S.J., S., Thorpe, W., 1999. Smallholder Dairy Technology in Coastal Kenya. An adoption and impact study, ILRI Impact Assessment Series 5.

Okan, Z., 2003. Edutainment: is learning at risk? Br. J. Educ. Technol. 34, 255-264. https://doi.org/10.1111/1467-8535.00325

Omiti, J., Otieno, D., Nyanamba, T., McCullough, E., 2009. Factors influencing the intensity of market participation by smallholder farmers: A case study of rural and peri-urban areas of Kenya. Ajfare 3, 57-82.

Pretty, J.., Morison, J.I.., Hine, R.., 2003. Reducing food poverty by increasing agricultural sustainability in developing countries. Agric. Ecosyst. Environ. 95, 217-234. https://doi.org/10.1016/S0167-8809(02)00087-7

Staal, S.., Baltenweck, I., Waithaka, M.., deWolff, T., Njoroge, L., 2002. Location and uptake: integrated household and GIS analysis of technology adoption and land use, with application to smallholder dairy farms in Kenya. Agric. Econ. 27, 295-315. https://doi.org/10.1016/S01695150(02)00075-0

Teklewold, H., Kassie, M., Shiferaw, B., 2013. Adoption of Multiple Sustainable Agricultural Practices in Rural Ethiopia. J. Agric. Econ. 64, 597-623. https://doi.org/10.1111/1477-9552.12011 


\section{Appendix}

Table A.1: Correlation between responses to statements related farmers' perceptions and views on farming

\begin{tabular}{|c|c|c|c|c|c|c|c|c|c|c|}
\hline & $\begin{array}{l}\text { I would } \\
\text { use } \\
\text { other } \\
\text { inputs if } \\
\text { they } \\
\text { were } \\
\text { cheaper }\end{array}$ & $\begin{array}{l}\text { I find it } \\
\text { difficult to } \\
\text { find the } \\
\text { material, } \\
\text { inputs needed } \\
\text { to make } \\
\text { changes }\end{array}$ & $\begin{array}{l}\text { My } \\
\text { supplier } \\
\text { provides } \\
\text { me with all } \\
\text { information } \\
\text { about } \\
\text { inputs and } \\
\text { material }\end{array}$ & $\begin{array}{l}\text { I do not } \\
\text { know } \\
\text { who to } \\
\text { contact } \\
\text { about } \\
\text { inputs, } \\
\text { materials }\end{array}$ & $\begin{array}{l}\text { My farm is } \\
\text { too small } \\
\text { for me to } \\
\text { care about } \\
\text { making any } \\
\text { changes }\end{array}$ & $\begin{array}{l}\text { I like to } \\
\text { try new } \\
\text { things in } \\
\text { my farm }\end{array}$ & $\begin{array}{l}\text { I am } \\
\text { sceptical } \\
\text { that new } \\
\text { technolo } \\
\text { gies will } \\
\text { work }\end{array}$ & $\begin{array}{l}\text { I enjoy } \\
\text { farming }\end{array}$ & $\begin{array}{l}\text { I see } \\
\text { farming } \\
\text { as a } \\
\text { business }\end{array}$ & $\begin{array}{l}\text { I see } \\
\text { farming } \\
\text { as a way } \\
\text { to feed } \\
\text { the } \mathrm{HH}\end{array}$ \\
\hline $\begin{array}{l}\text { I would use other inputs if } \\
\text { they were cheaper }\end{array}$ & 1.00 & & & & & & & & & \\
\hline $\begin{array}{l}\text { I find it difficult to find the } \\
\text { material, inputs needed to } \\
\text { make changes }\end{array}$ & 0.13 & 1.00 & & & & & & & & \\
\hline $\begin{array}{l}\text { My supplier provides me } \\
\text { with all information about } \\
\text { inputs and material }\end{array}$ & -0.18 & -0.08 & 1.00 & & & & & & & \\
\hline $\begin{array}{l}\text { I do not know who to contact } \\
\text { about inputs, materials }\end{array}$ & -0.78 & 0.31 & 0.01 & 1.00 & & & & & & \\
\hline $\begin{array}{l}\text { My farm is too small for me } \\
\text { to care about making any } \\
\text { changes }\end{array}$ & -0.15 & 0.13 & 0.14 & 0.32 & 1.00 & & & & & \\
\hline $\begin{array}{l}\text { I like to try new things in my } \\
\text { farm }\end{array}$ & 0.24 & -0.03 & 0.01 & -0.07 & -0.13 & 1.00 & & & & \\
\hline $\begin{array}{l}\text { I am sceptical that new } \\
\text { technologies will work }\end{array}$ & -0.20 & 0.06 & 0.18 & 0.20 & 0.19 & 0.00 & 1.00 & & & \\
\hline I enjoy farming & 0.33 & -0.03 & -0.05 & -0.06 & -0.14 & 0.31 & -0.02 & 1.00 & & \\
\hline I see farming as a business & 0.25 & -0.07 & 0.01 & -0.05 & -0.12 & 0.36 & -0.03 & 0.52 & 1.00 & \\
\hline $\begin{array}{l}\text { I see farming as a way to } \\
\text { feed the } \mathrm{HH}\end{array}$ & 0.25 & 0.02 & 0.00 & -0.03 & -0.09 & 0.28 & 0.04 & 0.45 & 0.46 & 1.00 \\
\hline
\end{tabular}


Table A.2: Cluster analysis

\begin{tabular}{lcc}
\hline & Group F1 & Group F2 \\
\hline I would use other inputs if they were cheaper & $4.40^{\mathrm{a}}$ & $3.66^{\mathrm{b}}$ \\
\hline I find it difficult to find the material, inputs needed to make changes & $3.05^{\mathrm{a}}$ & $3.50^{\mathrm{b}}$ \\
\hline My supplier provides me with all information about inputs and material & $2.57^{\mathrm{a}}$ & $3.00^{\mathrm{b}}$ \\
\hline I do not know who to contact about inputs, materials & $2.27^{\mathrm{a}}$ & $3.44^{\mathrm{b}}$ \\
\hline My farm is too small for me to care about making any changes & $1.79^{\mathrm{a}}$ & $3.32^{\mathrm{b}}$ \\
\hline I like to try new things in my farm & $4.30^{\mathrm{a}}$ & $3.75^{\mathrm{b}}$ \\
\hline I am sceptical that new technologies will work & $2.79^{\mathrm{a}}$ & $3.50^{\mathrm{b}}$ \\
\hline I enjoy farming & $4.68^{\mathrm{a}}$ & $4.28^{\mathrm{b}}$ \\
\hline I see farming as a business & $4.63^{\mathrm{a}}$ & $4.17^{\mathrm{b}}$ \\
\hline I see farming as a way to feed the HH & $4.74^{\mathrm{a}}$ & $4.40^{\mathrm{b}}$
\end{tabular}

Average scores between groups were statistically tested for significant difference. Scores followed by the same letters are not statistically different at 0.05 level. 
Table A.3a: Marginal effects on the probability of implementing individual agricultural practices in the last 12 months/season for maize farmers

\begin{tabular}{|c|c|c|c|c|c|}
\hline & $\begin{array}{l}\text { Apply fertilizer at } \\
\text { planting }\end{array}$ & $\begin{array}{l}\text { Apply fertilizer } \\
\text { mixed with manure } \\
\text { at planting }\end{array}$ & $\begin{array}{l}\text { Apply manure at } \\
\text { planting }\end{array}$ & $\begin{array}{l}\text { Purchase maize seed } \\
\text { from an agro- } \\
\text { dealer/shop }\end{array}$ & $\begin{array}{l}\text { Plant a crop in your } \\
\text { maize plot as an } \\
\text { intercrop }\end{array}$ \\
\hline SSU viewers & $0.109 * * *$ & $0.072 *$ & -0.023 & $0.098 * * *$ & 0.028 \\
\hline F1M - Education/Usefulness & -0.004 & -0.002 & 0.008 & 0.004 & 0.025 \\
\hline F2M - Empathy & $0.047^{* *}$ & $-0.028 * * *$ & -0.005 & -0.024 & $0.043 * *$ \\
\hline F3M - Entertainment/fun & 0.019 & -0.011 & $0.032 * *$ & $0.039 * *$ & 0.027 \\
\hline F4M - Entertainment/friends & 0.003 & 0.001 & $-0.062 * * *$ & $-0.056 * * *$ & $-0.044^{* *}$ \\
\hline Media_trust (TV news, magazines) & $-0.054 * * *$ & $0.015^{*}$ & $0.027^{* *}$ & 0.004 & $0.001 *$ \\
\hline External1_trust (Agrodealers, agrivet) & $0.025^{*}$ & 0.007 & 0.011 & 0.003 & -0.013 \\
\hline External2_trust (Ag. Extension officer, NGO) & $0.0254^{*}$ & $0.014 *$ & $-0.034 * * *$ & 0.020 & -0.015 \\
\hline Traditional_trust (friends, family) & $-0.044^{* * *}$ & -0.002 & -0.002 & $-0.030 * *$ & $-0.043 * * *$ \\
\hline Farmer's Age & -0.002 & $0.001 *$ & $0.002 * *$ & 0.001 & 0.001 \\
\hline Gender & -0.031 & -0.001 & 0.032 & $-0.054 *$ & -0.022 \\
\hline Primary education & 0.056 & -0.013 & -0.001 & $0.103^{*}$ & -0.042 \\
\hline Secondary education & 0.066 & -0.021 & -0.028 & $0.129 * *$ & -0.017 \\
\hline Higher education & $0.127^{*}$ & -0.023 & -0.042 & $0.177^{* * *}$ & 0.039 \\
\hline Cluster F1 & -0.016 & $-0.070 * * *$ & 0.023 & 0.003 & 0.042 \\
\hline $\mathrm{HH}$ female ratio & $-0.145^{* *}$ & -0.028 & -0.045 & $-0.149 * *$ & -0.076 \\
\hline $\mathrm{HH}$ children ratio & $0.255^{* * *}$ & $-0.079 * *$ & -0.038 & 0.089 & 0.057 \\
\hline Cropland area & -0.006 & -0.003 & 0.008 & 0.010 & -0.007 \\
\hline Normal PPI & -0.052 & $0.097^{* *}$ & $0.067^{*}$ & 0.057 & 0.046 \\
\hline High PPI & $-0.103 *$ & $0.112^{* *}$ & $0.104 * *$ & 0.002 & 0.018 \\
\hline Conditional probability (model) & 0.53 & 0.09 & 0.19 & 0.61 & 0.48 \\
\hline Probability (sample) & 0.53 & 0.08 & 0.21 & 0.61 & 0.48 \\
\hline
\end{tabular}


Table A.3b: Marginal effects on the probability of implementing individual agricultural practices in the last 12 months/season for maize farmers

\begin{tabular}{|c|c|c|c|c|c|}
\hline & $\begin{array}{l}\text { Purchased packed } \\
\text { seeds for intercropping } \\
\text { from a shop/agro } \\
\text { dealer }\end{array}$ & $\begin{array}{c}\text { Planted your maize } \\
\text { at this distance } 2.5 \\
\text { feet } / 75 \mathrm{~cm} \text { between } \\
\text { rows and } 1 \\
\text { foot } / 30 \mathrm{~cm} \text { between } \\
\text { plants }\end{array}$ & $\begin{array}{l}\text { Apply top dressing } \\
\text { fertilizer }\end{array}$ & $\begin{array}{l}\text { Weed your maize two } \\
\text { times (or more) }\end{array}$ & $\begin{array}{l}\text { Use Actellic in your } \\
\text { stored maize }\end{array}$ \\
\hline SSU viewers & 0.004 & $-0.123 * *$ & $0.076 * *$ & 0.045 & $0.050 * *$ \\
\hline F1M - Education/Usefulness & $0.029 * *$ & $0.050 * * *$ & -0.011 & 0.018 & 0.015 \\
\hline F2M - Empathy & 0.012 & 0.017 & -0.031 & 0.026 & 0.001 \\
\hline F3M - Entertainment/fun & 0.008 & -0.003 & $-0.030 *$ & 0.019 & 0.009 \\
\hline F4M - Entertainment/friends & $-0.022 *$ & 0.004 & $-0.057 * * *$ & $-0.060^{*}$ & $-0.047^{* * *}$ \\
\hline Media_trust (TV news, magazines) & $-0.022 * *$ & $0.054 * * *$ & $-0.035^{* *}$ & -0.010 & -0.01 \\
\hline External1_trust (Agrodealers, agrivet) & 0.003 & 0.010 & 0.007 & -0.013 & 0.004 \\
\hline External2_trust (Ag. Extension officer, NGO) & -0.003 & $-0.070 * * *$ & $0.035 * * *$ & -0.021 & 0.003 \\
\hline Traditional_trust (friends, family) & -0.012 & $-0.030 * *$ & -0.009 & $-0.032 * *$ & 0.003 \\
\hline Farmer's Age & -0.001 & 4.E-04 & 0.001 & -0.001 & $-4 . E-04$ \\
\hline Gender & 0.025 & 5.E-05 & 0.002 & -0.024 & -0.010 \\
\hline Primary education & 0.034 & -0.020 & $0.207^{* * *}$ & 0.014 & -0.019 \\
\hline Secondary education & 0.039 & -0.006 & $0.294 * * *$ & 0.037 & 0.050 \\
\hline Higher education & 0.044 & 0.077 & $0.355^{* * *}$ & 0.067 & 0.109 \\
\hline Cluster F1 & $0.044^{* *}$ & 0.035 & 0.037 & $-0.066 * *$ & 0.022 \\
\hline HH female ratio & -0.047 & -0.098 & -0.074 & -0.083 & -0.066 \\
\hline $\mathrm{HH}$ children ratio & -0.019 & 0.062 & $0.120^{*}$ & 0.001 & 0.082 \\
\hline Cropland area & 0.003 & -0.007 & $0.017^{* * *}$ & 0.006 & $0.023 * * *$ \\
\hline Normal PPI & 0.039 & 0.001 & 0.026 & 0.029 & $0.079 * *$ \\
\hline High PPI & 0.033 & -0.025 & 0.035 & -0.078 & 0.055 \\
\hline Conditional probability (model) & 0.10 & 0.28 & 0.34 & 0.57 & 0.16 \\
\hline Probability (sample) & 0.11 & 0.28 & 0.35 & 0.57 & 0.18 \\
\hline
\end{tabular}


Table A.4a: Marginal effects on the probability of implementing individual agricultural practices in the last 12 months/season for dairy farmers

\begin{tabular}{lcccc} 
& $\begin{array}{c}\text { Increase the size } \\
\text { of your dairy head }\end{array}$ & $\begin{array}{c}\text { Increase the area of } \\
\text { Napier grass }\end{array}$ & $\begin{array}{c}\text { Feed cows using } \\
\text { chopped Napier } \\
\text { grass }\end{array}$ & $\begin{array}{c}\text { Spray dairy cows } \\
\text { for ticks or lice }\end{array}$ \\
\hline SSU viewers & 0.046 & $0.056^{* *}$ & $0.090^{* *}$ & 0.015 \\
F1D - Education/Usefulness/empathy & 0.011 & $0.032^{*}$ & -0.009 & -0.016 \\
F2D - Entertainment/fun & 0.017 & 0.002 & -0.036 & -0.004 \\
F3D - Entertainment/friends & -0.009 & $-0.047^{* *}$ & $-0.061^{* *}$ & -0.027 \\
Media_trust (TV news, magazines) & -0.005 & -0.013 & $0.055^{* *}$ & $0.059^{* * *}$ \\
External1_trust (Agrodealers, agrivet) & -0.018 & 0.006 & $0.036^{*}$ & 0.020 \\
External2_trust (Ag. Extension officer, NGO) & $-0.023^{*}$ & -0.017 & -0.004 & $0.081^{* * *}$ \\
Traditional_trust (friends, family) & 0.012 & 0.012 & 0.016 & -0.007 \\
Farmer's Age & 0.001 & 0.001 & $0.005^{* * *}$ & $-1 . \mathrm{E}-04$ \\
Gender & -0.021 & 0.011 & 0.043 & -0.026 \\
Primary education & 0.064 & 0.100 & $0.217^{* *}$ & $0.117^{*}$ \\
Secondary education & 0.089 & $0.158^{*}$ & $0.241^{* * *}$ & 0.055 \\
Higher education & $0.180^{*}$ & $0.206^{*}$ & $0.216^{* *}$ & 0.050 \\
Cluster F1 & 0.006 & -0.022 & $0.072^{*}$ & -0.009 \\
HH female ratio & -0.019 & -0.011 & -0.045 & -0.010 \\
HH children ratio & $0.146^{* *}$ & 0.017 & -0.007 & 0.039 \\
Number of cows & $0.017^{* * *}$ & -0.002 & $-0.060^{* * *}$ & 0.003 \\
Normal PPI & 0.017 & $0.119^{* *}$ & $0.287^{* * *}$ & $0.092^{*}$ \\
High PPI & 0.004 & 0.111 & $0.362^{* * *}$ & $0.128^{* *}$ \\
\hline Conditional probability (model) & 0.17 & 0.13 & 0.44 & 0.76 \\
Probability (sample) & 0.18 & 0.15 & 0.46 & 0.74 \\
\hline
\end{tabular}


Table A.4b: Marginal effects on the probability of implementing individual agricultural practices in the last 12 months/season for dairy farmers

\begin{tabular}{|c|c|c|c|}
\hline $\begin{array}{l}\text { Deworm your } \\
\text { dairy cows }\end{array}$ & Treat for mastitis & $\begin{array}{l}\text { Purchase } \\
\text { supplement feeds } \\
\text { or salt licks }\end{array}$ & $\begin{array}{l}\text { Ensure cows } \\
\text { have enough } \\
\text { water all day }\end{array}$ \\
\hline
\end{tabular}

\begin{tabular}{|c|c|c|c|c|}
\hline SSU viewers & 0.046 & 0.026 & $0.088^{* *}$ & 0.166 \\
\hline F1D - Education/Usefulness/empathy & -0.030 & $0.035^{* *}$ & $-0.051^{*}$ & -0.094 \\
\hline F2D - Entertainment/fun & -0.014 & $-0.2 E-4$ & $-0.052^{*}$ & -0.055 \\
\hline F3D - Entertainment/friends & 0.014 & -0.025 & 0.011 & 0.118 \\
\hline Media_trust (TV news, magazines) & $0.050 * * *$ & 0.019 & $0.067 * * *$ & $0.163 * * *$ \\
\hline External1_trust (Agrodealers, agrivet) & $0.026 * *$ & 0.020 & -0.015 & $0.125^{* *}$ \\
\hline External2_trust (Ag. Extension officer, NGO) & $0.070 * * *$ & 0.011 & $0.036^{*}$ & $0.161 * * *$ \\
\hline Traditional_trust (friends, family) & $0.021 *$ & -0.007 & 0.024 & $0.125^{* * *}$ \\
\hline Farmer's Age & 0.001 & 0.001 & $-5 . E-04$ & $0.009 * *$ \\
\hline Gender & -0.034 & 0.019 & 0.032 & -0.023 \\
\hline Primary education & 0.013 & 0.102 & 0.031 & $0.663^{* * *}$ \\
\hline Secondary education & -0.044 & $0.146 *$ & 0.007 & $0.542 * *$ \\
\hline Higher education & -0.029 & 0.185 & 0.068 & $0.435^{*}$ \\
\hline Cluster F1 & $0.097^{* * *}$ & 0.024 & $0.133^{* * *}$ & $0.172 *$ \\
\hline HH female ratio & -0.028 & 0.001 & -0.111 & 0.169 \\
\hline $\mathrm{HH}$ children ratio & -0.062 & 0.030 & -0.069 & 0.024 \\
\hline Number of cows & -0.003 & 0.005 & -0.013 & $-0.046^{*}$ \\
\hline Normal PPI & -0.005 & $0.104 * *$ & 0.070 & $0.512^{* * *}$ \\
\hline High PPI & 0.032 & 0.099 & $0.177^{* * *}$ & $0.921 * * *$ \\
\hline Conditional probability (model) & 0.85 & 0.14 & 0.66 & 0.57 \\
\hline Probability (sample) & 0.83 & 0.15 & 0.65 & 0.53 \\
\hline
\end{tabular}

